\title{
War and the Constitutional Text
}

\author{
John C. Yoo†
}

This Response to Professor Ramsey's pro-Congress view of the war powers debate presents a complete textual and structural theory of a flexible approach to war powers. Under this flexible system, the President possesses the power to initiate and conduct hostilities as commander-in-chief and chief executive under Article II of the Constitution, checked by Congress's power of the purse. The Declare War Clause simply confers on Congress juridical power to both deflne the United States's legal relations with other countries and trigger domestic constitutional authorities during wartime. How the nation goes to war will result from the interaction of the political branches using these plenary constitutional powers. The Response first critiques Professor Ramsey's historical account, which does not address the full context of the framing, and next argues that constitutional text and structure support the flexible war powers system understood by the framing generation. Critics of this approach fail to appreciate the textual significance of the authority independently granted to the President by the Commander-in-Chief and Executive Power Clauses and the "engage in War" language of Article I, Section 10. In addition, they do not appreciate the manner in which the Constitution structures the interaction of executive and legislative branches by creating strict processes with carefully defined roles for the President and Congress, as with the enactment of legislation, in contrast to areas where it does not, as with warmaking. A more comprehensive reading of the text and structure demonstrates that the Constitution does not mandate a specific, legalistic process for waging war. Instead, the Constitution vests the executive and legislative branches with different powers involving war, which the President and Congress may use to cooperate or to compete for control over warmaking.

\section{INTRODUCTION}

In a series of articles, I have criticized the view that the original understanding of the Constitution requires that Congress provide its authorization before the United States can engage in military hostilities. This "pro-Congress" position ignores the constitutional text and

$\dagger$ Professor of Law, University of California at Berkeley School of Law (Boalt Hall) (on leave); Deputy Assistant Attorney General, Office of Legal Counsel, United States Department of Justice. The views expressed here are those of the author alone and do not represent the views of the Department of Justice. I express ny deep appreciation for the advice and assistance of James C. Ho in preparnitg this response. Robert Delahunty, Jack Goldsmith, Sai Prakash, and Brad Clark provided helpful comments on the draft.

1 See John C. Yoo, Kosovo, War Powers, and the Multilateral Future, 148 U Pa L Rev 1673, 1686-1704 (2000) (discussing the oxiginal understanding of war powers in the context of the Kosovo conflict); John C. Yoo, Clio at War: The Misuse of History in the War Powers Debate, $70 \mathrm{U}$ Colo L Rev 1169, 1221 (1999) (arguing that "the Constitution provides for a flexible arrangenent of foreign affairs powers within some fairly broad parameters"); John C. Yoo, The Con- 
structure, errs in interpreting the ratification history of the Constitution, and cannot account for the practice of the three branches of government. Instead of the rigid process advocated by scholars such as Louis Henkin, John Hart Ely, Louis Fisher, Michael Glennon, and Harold Koh, ${ }^{2}$ I have argued that the Constitution creates a flexible system of war powers. That system provides the President with significant initiative as commander-in-chief, while reserving to Congress ample authority to check executive policy through its power of the purse. In this scheme, the Declare War Clause confers on Congress a juridical power, one that both defines the state of international legal relations between the United States and another country and triggers domestic constitutional authorities during wartime. ${ }^{3}$

In Textualism and War Powers, ${ }^{4}$ Professor Michael D. Ramsey agrees with much of my work and does me the honor of recognizing me as a leading proponent of a pro-executive theory of war powers. He agrees that pro-Congress scholars have not advanced a convincing textual defense of their views, and that they have been unable to explain the historical evidence that favors presidential control over the initiation of military hostilities. Professor Ramsey even concedes that by the eighteenth century, formal declarations of war were unnecessary to authorize the conduct of military hostilities. Professor Ramsey acknowledges that the pro-Congress position suffers from a "serious textual einbarrassment," because the constitutional text only grants Congress "the power 'to declare war,' not the power 'to authorize hos-

tinuation of Politics by Other Means: The Original Understanding of War Powers, 84 Cal L Rev 167, 188-296 (1996) (arguing from eighteenth-century British and American sources that the Constitution does not shift war powers from the President to Congress).

2 See, for example, William M. Treanor, Fame, the Founding, and the Power to Declare War, 82 Cornell L Rev 695, 700 (1997) ("The Founders intended that the [Declare War] Clause would vest in Congress principal responsibility for initiating conflict."); Louis Fisher, Presidential War Power 203 (Kansas 1995) (stating that Congress needs to "rediscover its institutional and constitutional duties" and that "[1] egislators must be prepared, and willing, to use the ample powers at their disposal"); John Hart Ely, War and Responsibility: Constitutional Lessons of Vietnam and Its Aftermath 3 (Princeton 1993) ("The power to declare war was constitutionally vested in Congress" in order to "reduce the number of occasions on which [the United States] would become [ ] involved."); Michael J. Glennon, Constitutional Diplomacy 81 (Princeton 1990) ("There is no evidence that the Framers intended to confer upon the President any independent authority to coinunit the armed forces to combat, except in order to repel 'sudden attacks."'); Louis Henkin, Constitutionalism, Democracy, and Foreign Affairs 109 (Columbia 1990) (arguing that Congress is the "rudder" that steers the Constitution in foreign affairs matters); Harold Hongju Koh, The National Security Constitution: Sharing Power after the Iran-Contra Affair 158-61 (Yale 1990) (noting that the trend has been toward increasing executive control but arguing for more balanced power sharing).

3 See Yoo, 84 Cal L Rev at 204-08, 242-50 (cited in note 1).

4 Michael D. Ransey, Textualism and War Powers, 69 U Chi L Rev 1543 (2002). 
tilities,' and it is not immediately clear why the two should be equated."

Nonetheless, Professor Ramsey believes that the pro-Congress school has things right. In fact, his interpretation of the Constitution is identical to the rest of the pro-Congress camp: Congress inust approve all uses of military force by the President, unless the nation is acting im its self-defense, because Congress enjoys the sole authority to declare war. Textualism and War Powers not only revives the usual proCongress reading of the Declare War Clause, but it also relies on the same interpretation of the drafting of the Clause repeatedly brouglit forth by pro-Congress scholars.

What new argument does Professor Ramsey add to the debate? It is the claim that the pro-Congress view is supported by the writmgs of some eighteenth-century European legal writers, who allegedly believed that war could be declared either by "word" or by "action." The core of Professor Ramsey's argument is that these writers seeined to believe that formal declarations of war served no real purpose under international law, and that their rlietorical use of the phrase "declaring war" demonstrates that the term, as used in Article I, must have been meant to give Congress the power to commence lostilities, either througl a formal declaration (declaring by "word") or by launcling an attack (declaring by "action"). Professor Ramsey lias reached the very same destmation as Professors Ely, Glennon, Henkin, and Koh; he has only added an extra twist in the road.

As a resnlt, Professor Ramsey's addition to the pro-Congress argument does not advance a new understanding of the constitutional text and structure, or develop a different history of its drafting and ratification. In fact, he passes over the former, despite his claim of providing a textual theory of war powers, and fails to respond to the cliallenges of the latter. I welcome the opportuinty to reply, because it allows me to develop a inore comprehensive explanation of why the constitutional text and structure create a less legalistic, more flexible war powers system. Prominent defenders of a pro-executive approach to war powers generally emphasize the President's functional superiority to Congress $\mathrm{m}$ foreigu affairs and war. ${ }^{6}$ Others, such as Professor

5 Id at 1552. Oddly, Professor Ramsey goes to great lengths to create daylight between his reading of the meaning of a declaration of war during the eighteenth century and mine. He reads my work as concluding that a declaration of war was "prerequisite to the invocation of the laws of war," id at 1588 \& n 176, but admits that elsewhere I view the declaration as a notification of an existing legal status. In fact, I recognized that different international authorities thought that a declaration could perform either role; but the important point was that neither function encoinpassed the idea that a declaration was necessary to commence hostilities. See Yoo, $84 \mathrm{Cal} \mathrm{L}$ Rev at $207-08$ (cited in note 1).

6 Judge Robert H. Bork has written: "The respective roles of Congress and the president 
Henry Monaghan, have emphasized the practice in which presidents often have initiated military hostilities without a declaration of war.' Pro-executive scholarship, however, has not offered a detailed textual and structural examination of war powers. Here I will provide a more complete textual and structural theory of a flexible approach to war powers that provides presidents with the authority to initiate hostilities.

It is important to understand what is at stake. Like others in the pro-Congress camp, Professor Ramsey appears to beheve that many of the wars of the last half-century have violated the Constitution. Thus, President Truman's use of force in the Korean War, President Johnson and Nixon's expansion of the Vietnam War, ${ }^{8}$ and our interventions in places hike Grenada, Panama, Bosnia, and Kosovo, were all illegal because they were not accompamed by a declaration of war or its functional equivalent. The implications of Professor Ramsey's views are not limited merely to the past. We are in the midst of a terrible war against a determmed terrorist enemy, one which disregards the laws of war, operates at a global level, and wields the resources and capability for violence of a nation-state. Professor Ramsey, like others who find such significance im the Declare War Clause, would require the President to receive the permission of Congress before he could attack such terrorist groups and the nations that harbor or support them.' Moreover, as the nation now considers its policy toward despotic regimes that are developing weapons of mass destruction, such as Iraq, Professor Ramsey and other pro-Congress advocates would require Congress to approve a declaration of war or authorization, with its attendant public debate, before the President could launch an attack.

developed according to their structural capacities and limitations. Congress, consisting of 535 neinbers assisted by huge staffs, is obviously incapable of swift, decisive, and flexible action in the employment of armed force." Robert H. Bork, in L. Gordon Crovitz and Jeremy A. Rabkin, eds, The Fettered Presidency: Legal Constraints on the Executive Branch Foreward at x (AEI 1989). See also Robert H. Bork, Erosion of the President's Power in Foreign Affairs, 68 Wash U L Q 693,698 (1990) (noting that the "the War Powers Act is ineffective because it seeks to involve Congress in something it is institutionally incapable of handling: swift responses with military force").

7 As Professor Monaghan has observed, a "practice so deeply embedded in our governmental structure should be treated as decisive of the constitutional issue." Henry P. Monaghan, Presidential War-making, 50 BU L Rev 19, 31 (1970 special issue). See also J. Terry Emerson, War Powers Legislation, $74 \mathrm{~W}$ Va L Rev 53, 72 (1971) (arguing that history denonstrates that the President has broad authority to use military force independently).

8 Assuming for the moment that the Tonkin Gulf Resolution was not itself sufficient to authorize attacks on North Vietnam, Laos, or Canbodia.

9 To date, Congress has only authorized the use of force against terrorists that participated in the attacks on the World Trade Center and the Pentagon on September 11,2001. See Authorization for Use of Military Force, Pub L No 107-40,115 Stat 224 (2001). 
This response will explain why the constitutional text, structure, and history establish a different framework, one flexible enough to accommodate the realities of the modern world. Part I begims by addressing Professor Ramsey's claim that the original understanding supports a pro-Congress understanding of war powers. It identifies limitations in Professor Ramsey's use of historical materials, and it explains why the original understanding of the Constitution, properly understood, supports a more flexible approach to war powers. Part II discusses the textual foundations of this system, and Part III examines its structural imperatives.

\section{Historical PRoblems WITH THE PRO-CONGRESS Position}

Rather than directly addressing the textual and structural arguments in favor of a pro-executive approach to war powers, Professor Ramsey (like most pro-Congress scholars) relies entirely on history. In an effort to discern the original understanding of the Declare War Clause, Professor Rainsey first argues that interuational legal scholars of the eighteenth century had come to realize that declarations of war had almost no purpose. In this regard, lie attempts to go beyond my 1996 article in the California Law Review, which found few declarations of war in eighteenth-century British practice and therefore concluded that they were not considered necessary for the initiation of hostilities. ${ }^{10}$ Second, he claims that the irrelevance of declarations of war means that the Declare War Clause actually must confer a far broader power, because otherwise there was no poimt in transferring the authority from the executive to Congress. He then draws the true meaning of declaring war from rhetorical statements about war by eighteenth-century thinkers, Locke, and contemporaneous Britisli legal works. He concludes that these thinkers believed the phrase "declare war" to mean beginning a war either by issuing a declaration of war ("by word") or by siniply launching an attack ("by action").

This Part criticizes Professor Ramsey's treatment of the original understanding. Professor Ramsey's response to pro-executive scholars is that the meaning of the Declare War Clause is so plain that no resort to contextual evidence is necessary. ${ }^{11}$ Professor Ramsey's historical evidence must clear a high hurdle if it is to overcome the textual and structural arguments - to be more fully explored in Parts II and

10 See Yoo, 84 Cal L Rev at 214-17 (cited in note 1).

11 See Ramsey, 69 U Chi L Rev at 1602 (cited in note 4). Professor Ramsey's effort to unearth the eighteenth-century meaning of "declare war," which consumes inost of his article's energy, seeks to prove that the text's meaning is indeed plain. Of course, if he were right, we would not have to examine the history at all, and his reliance upon it demonstrates that his textual arguments, such as they are, really do not resolve the question. 
III-in favor of a flexible system characterized by presidential initiative and leadership.

Professor Ramsey's history fails to meet this standard. His approach to the eighteenth-century inaterials suffers the symptoins of "law-office" history. He uses sources incompletely, he does not address conflicting evidence, he does not examme the historical context of the evidence, and he neglects the secondary historical works on the period. A fundamental lack of historical context leads him to ignore the significant political and constitutional changes that occurred during the colonial, revolutionary, and critical periods in early American history. Professor Ramsey fails to trace developments in American thinking about constitutional, foreign affairs, or the war power during the tumultuous years between the Revolution and the Ratification. As a result, Professor Ransey considers Sir Matthew Hale's 1672 comments on declaring war to be as significant as James Madison's more than a century later.

These problems in his use of history lead Professor Rainsey to struggle mightily to show that everyone in the Anglo-American world of the eighteenth century shared the same basic understanding of declaring war. Real history sunply does not bear this out. Professor Ramsey overstates the agreement, if there was any, among scholars concerning declarations of war. Further, he focuses on their rhetorical uses of "declaring war" while ignoring the specific legal definition given to the phrase by some of the same authors im the same works. Professor Ransey's most serious misstep is his inattention to the actual events of the constitutional history of the framing generation. He assumes that the Framers would have been nore familiar with the musings of a Hale or Rutherforth - both of whom, it appears, were never seriously discussed in the pubhic political literature of the framing $^{12}$-than with the actual political events that led to the break with Great Britain and the ratification of the Constitution. Further, Professor Ramsey ignores clear examples in which the Framers directly drew upon these events to predict the operation of the Constitution's system of war powers. In discovering the original understanding of war powers, it is more inportant to reveal how the Framers thought that the Constitution would work, rather than what distant commentators rhetorically said about declaring war as an abstract inatter.

12 See Donald S. Lutz, The Origins of American Constitutionalism 141-45 (Louisiana State 1988) (charting sources most cited in American political literature during critical and ratification periods). 


\section{A. The Standards of History}

Professor Ramsey paints his picture on a broad canvas. He seeks to show that international legal authorities, beginning with Grotius, extending through Wolff, Burlamaqui, and Vattel, and presumably ending in the ratification, developed the idea that declaring war meant commencing war either by word or by deed. A more careful examination of the sources, however, indicates that Professor Rainsey misreads agreement annong these observers and has ignored thinkers who were more important and well-known to the Framers. Professor Rainsey also inakes serious inethodological errors that undermine his conclusions. He never exammes the nature of Anglo-American constitutional developinent during the eighteenth century, nor does he seek to understand the war powers issue as part of the changes im American political thought that led to the Constitution. Examination of this context shows that Professor Ransey's story is out-of-step with the history of the Constitution's ratification.

While the thoughts of various European and British legal scholars on declaring war are interesting, they are not relevant unless incorporated into the developinents leading to the Constitution's creation. In other words, it does not matter much what Rutherforth thought of British war powers practice, or what Bynkershoek believed to be the Netherlands constitution's war powers, unless we know whether these ideas actually influenced the framing generation. Further, we caimot evaluate the import of these works without understanding the broader historical trends of the revolutionary and ratification periods. In order to reconstruct the original understanding of the war power properly, common sense-if not the pleas of legal historians and legal scholars who care about history-tells us that a scholar must do a good job of using history.

Unfortunately, Professor Ramsey's account does not ineet these standards. First, he does not take an appropriately broad approach to the primary sources of the ratification period, but instead focuses on only a narrow shver-eighteenth-century treatises on international law, to be exact. Situating the ideas and concepts we argue about today in their historical setting invariably helps us understand more about thein. We can better comprehend the contours and nature of the presidency, for example, by examining what intellectual trends and constitutional developinents-the early state experiments with a fraginented executive branch and the return to a unitary executivegave rise to it. ${ }^{13} \mathrm{~A}$ more complete understanding of war powers, there-

13 This does not mean, of course, that there is full agreement on the exact nature of the executive power or the presidency. Consider Steven G. Calabresi and Saikrishna B. Prakash, The 
fore, requires us to examine not just the international legal thought concerning declarations of war (as Professor Ramsey does), but more importantly the domestic constitutional understandings, as reflected both in intellectual trends and in the actual events preceding the ratification. In contrast, Professor Ramsey's approach produces a nyopic effect, in which sinall differences are inagnified into distinctions of constitutional significance.

Thus, Professor Ramsey's use of the primary materials is incontplete because it does not integrate his account of eighteenth-century international legal thought into the other, most relevant primary materials involving war and the separation of powers. He has not produced any statements by actual Framers, such as Alexander Hamilton, James Madison, or James Wilson, that rely specifically on sources hike Rutherforth, Hale, or even Vattel on the question of war powers. Several of the authorities relied upon by Professor Ramsey were barely mentioned in the American political literature of the 1780s, while others-such as Montesquieu - who were the Framers' favorites go virtually unexamined. ${ }^{14}$ Professor Ramsey never explains how the power to declare war fit into the theories of the separation of powers advanced by Hamilton, Madison, or Wilson. From the way Professor Ramsey tells it, the Declare War Clause was its own independent book, with a complete beginining, middle, and end, rather than a theme running through the larger story of the framing.

Second, ignoring a basic rule for using history, Professor Ramsey fails to take account of the main secondary works on the framing pe-

President's Power to Execute the Laws, 104 Yale L J 541, 550 (1994) (arguing that "the originalist textual and historical arguments for the unitary Executive, taken together, firmly establish the theory" of the unitary Executive); Martin S. Flaherty, The Most Dangerous Branch, 105 Yale L J 1725, 1750-51 (1996) (noting widespread disagreenent among historians over separation-ofpowers scholarship).

14 Rutherforth, Hale, and Lee, whoin Professor Ramsey credits with the idea that a declaration of war was unnecessary, do not make one scholar's list of thinkers cited by the Framers. To make that list, a writer would have had to have been cited in at least one half of one percent of the political writing of the day. Lutz, Origins of American Constitutionalism at 142-45 (cited in note 12). While Professor Rainsey criticizes the Grotian view of declarations of war because it did not mirror reality and was rejected by those who followed, Grotius remained one of the inost cited thinkers on imternational law. See id at 142 , 145. In contrast, Burlamaqui, Wolff, and Bynkershoek, upon whom Professor Ramsey places great reliance, do not appear to have been discussed in even 0.5 percent of the Framing-era political hterature.

In iny earlier work on war powers, I focused most closely on Montesquieu and Blackstone. Professor Lutz has found thein to be the two most-cited secular thinkers of the Framing period. Id at 143. While, as we all know, citation rates do not correspond exactly to influence or the importance of a work, we can at least use citation works as a general proxy for the level of familiarity that the Framers would have had with an author's ideas. The three European thinkers who were the most influential on the thinking of the Franers-Montesquieu, Locke, and Blackstone-were also the most frequently cited. 
riod. Over the last fifty years, historians have produced a rich trove of works on the intellectual origins of the Revolution and the Constitution, including Bernard Bailyn's Ideological Origins of the American Revolution, Gordon Wood's The Creation of the American Republic, 1776-1787, Forrest McDonald's Novus Ordo Seclorum: The Intellectual Origins of the Constitution, and Jack Rakove's Original Meanings. ${ }^{\text {s }}$ Professor Ramsey does not attempt to distill the lessons of these secondary works, nor to place the developinents that he focuses onthe meaning of declaring war im eighteenth-century international legal theory-within the broader intellectual, political, and constitutional developments identified by these historians. ${ }^{16}$ As developed primarily by Professor Wood, American constitutional thought evolved during this period from a revolutionary behef that Americans were defending their riglits under the Britislı constitution, to failed state experiments im legislative supremacy during the period of initial independence, to the Thermidorean reaction that restored power to the unitary executive. ${ }^{17}$ I will describe low the executive's war powers at first suffered, then survived these changes im American constitutional design-in otlier words, my reading of the President's war powers is consistent

15 Bernard Bailyn, The Ideological Origins of the American Revolution (Harvard 1967); Gordon S. Wood, The Creation of the American Republic 1776-1787 (North Carolina 1969); Forrest McDonald, Novus Ordo Seclorum: The Intellectual Origins of the Constitution (Kansas 1985); Jack N. Rakove, Original Meanings: Politics and Ideas in the Making of the Constitution (Vintage Books 1996).

16 Constitutional historians have leveled this complaimt against similar original understanding scholarship. See, for example, Treanor, 82 Cornell L Rev at 756 (cited in note 2) ("[P]roCongress scholars have been unable to offer an explanation for why the founders thought that the power to initiate conflict should be exclusively vested in Congress."); Martin S. Flaherty, History "Lite" in Modern American Constitutionalism, 95 Colum L Rev 523, 525-26 (1995) (" $[\mathrm{H}] \mathrm{abits}$ of poorly supported generalization [] pervade the work of inany of the rigorous theorists when they imvoke the past to talk about the Constitution."). Flaherty has criticized some original understanding work that fails to give proper attention to facts, sources, and context, and notes that one sign of poor scholarship is a lack of "thorough reading, or at least citation, of both primary and secondary source inaterial generally recognized by historians as central to a given question." Id at 553. While I have iny disagreements on the historical merits with both Treanor, see Yoo, 70 U Colo L Rev at 1209-15 (cited in note 1), and Flaherty, see Joln C. Yoo, Treaties and Public Lawmaking: A Textual and Structural Defense of Non-Self-Execution, 99 Colum L Rev 2218, 2221-33 (1999), we agree on the basic standards that should guide the use of history in constitutional interpretation.

17 See generally Wood, Creation at 446-53 (cited in note 15). See also Marc Kruman, Between Authority \& Liberty: State Constitution Making in Revolutionary America at 109-30 (North Carolina 1997) (recounting the experiences of various colonies in balancing power between the legislative and executive branches); Forrest McDonald, The American Presidency: An Intellectual History 98-153 (Kansas 1995) (tracing the history of the presidency through colorial and revolutionary times); Willi Paul Adams, The First American Constitutions: Republican Ideology and the Making of the State Constitution in the Revolutionary Era 271-75 (North Carolina 1980) (Rita and Robert Kimber, trans); Charles C. Thach Jr., The Creation of the Presidency, 1775-1789: A Study in Constitutional History 34-35 (Johns Hopkins 1923) (examining the weaknesses of executives in colonial coustitutions during the revolutionary period). 
with the larger story of constitutional evolution. Because he ignores the broader historical context, Professor Ramsey cannot explain why the Framers would swim against the currents of history by transferring the power to initiate hostihities to the legislature when the Framers were restoring power to the Executive branch generally.

\section{B. The History of Early American Constitutional Development}

Putting aside these methodological disagreements, Professor Ramsey's history further falls short by failing to place his interpretation of eighteenth-century legal authorities in the context of early American constitutional thought. Professor Ramsey has written his article as if the Framers had so widely and completely agreed with an array of international legal scholars, ranging from the well-known to the obscure, that they never felt the need to explain publicly what they were doing. A better approach would examine not just a slice of the intellectual debates during this time, but, more importantly, the Framers' actual experience with war matters, with constitutionalism, and with the ratification. I have examined these developments and their import for the war powers debate elsewhere. ${ }^{18}$ Here, I will point out some significant historical issues that highlight the flaws in Professor Ramsey's account.

I have already briefly alluded to the general story of constitutional development during the franing period, as outlined by the wellknown work of Professor Gordon Wood. During the eighteenth century, the British constitutional system centralized executive power im the Crown. Defending what they initially viewed as their constitutional rights as British subjects, the American colonists believed that the Crown's usurpation of power had produced the oppressive measures that led to the Revolution. Once independent, the founding generation experimented with direct democracy and wrote their first state constitutions to expand the powers of their legislatures. These efforts produced chaos, leading some states to adopt admired constitutions that returned power to the executive branch. Following these changes, the Framers designed a new Constitution that restored powers to a presidency that once again enjoyed unity and independence." In evaluating Professor Wood's thesis, recent historical work has only emphasized that the idea of a separation of powers and a stronger executive took hold in the American political consciousness earlier and more deeply than thought.

18 See Yoo, 84 Cal L Rev at 196-294 (cited in note 1).

19 See generally Wood, Creation at 138, 393-429, 434 (cited in note 15 ).

20 See Kruman, Between Authority \& Liberty at 109-30 (cited in note 17) (emphasizing the 
Several points show that war powers generally tracked this basic account of American constitutional development. First, the British constitution clearly granted the Crown the power to initiate war. As the undisputed commander-in-chief of all military forces, the King could make war at his discretion. In fact, the constitutional struggles of the late seventeenth and early eighteenth centuries did not involve a question of the King's power over war, but the Parhament's control over the Crown's military activities through its power of the purse. By the tinie of the framing, the British pohtical system had reached a settlement in which Parhament's control over money gave it a functional veto over whether the nation would wage war. ${ }^{22}$ Not only was declaring war never mentioned as a significant constitutional power for separation of powers purposes, but declarations of war were rarely issued before or at the start of hostilities. No British subject-which is what, after all, the Franners had been-would have associated the power to declare war as a check on executive military action, because Parhament already enjoyed such authority through the funding power. During the ratifying conventions, as we will see, the Framers would have understood the allocation of the war power between the President and Congress against the historical baseline established by the struggle between the Crown and Parhament.

Second, the pre-ratification state constitutions and charters, which Professor Ramsey does not examme, either assumed that the executive possessed the power to begin hostilities, or vested such authority explicitly in the governor. In the area of foreign affairs, the first state constitutions generally reduced the executive not by transferring powers directly to the legislature, but by fraginenting the unity and independence of the executive througl advisory councils, multimember executives, or limited terms. ${ }^{23}$ Nonetheless, two constitutions that were widely admired by the Framers, those of New York and Massachusetts, bucked this trend and retamed in the executive the powers of coinmander-in-chief. These constitutions assumed that the executive contimued to possess the power to make war, and, unlike South Carolina's constitution, created no explicit requirement of consent by the legisla-

gubernatorial veto as evidence of colonial consciousness of the need for separation of powers and a stronger executive); McDonald, Novus Ordo Seclorum at 80-86 (cited in note 15) (discussing the influence of Montesquieu on American ideas of separation of powers); Adams, First American Constitutions at 256-75 (cited in note 17).

21 See Yoo, 84 Cal L Rev at 209-14 (cited in note 1) (discussing the struggle between Parliament and the King for the financial resources necessary to wage war).

22 See id. Parliament's creation and control over the financial systein niade possible Great Britain's rise to power during the eighteenth century. See generally John Brewer, The Sinews of Power: War, Money and the English State, 1688-1783 (Knopf 1989).

23 See Yoo, 84 Cal L Rev at 222-23 (cited in note 1). 
ture for warmaking. ${ }^{24}$ Massachusetts's 1780 constitution vested in the executive the full authority "to lead and conduct [the military], and with them to encounter, repel, resist, expel and pursue, by force of arms, as well by sea as by land, within or without the limits of this commonwealth" its enemies. ${ }^{25}$ These constitutions did not rely on the notion that declaring war was equivalent to commencing hostilities, and, indeed, none of them vested the legislature with the power to declare war in order to check the executive. Rather, the legislature continued to possess and exercise the same check enjoyed by Parliament: the power over funding.

Third, the leading constitutional thinkers of the day believed that the executive ouglit to have the power to initiate and conduct hostilities. Perhaps the three writers whom the Framers consulted most often on the separation of powers were Locke, Montesquieu, and Blackstone. ${ }^{26}$ All three indisputably believed that the executive should exercise full powers over the beginning and operation of war, subject to the legislature's power over funding. ${ }^{27}$ Blackstone in particular described declarations of war as only serving to notify the citizens of both nations that the sovereign had legally sanctioned the hostilities, rather than as a necessary constitutional step to be taken before hostilities could break out. These three writers were, far and away, the most respected authorities on the separation of powers among the Framers. One historian, for example, calculates that Montesquieu, Blackstone, and Locke, roughly in that order, were the most cited nonreligious thinkers in the political writing of the framing period. ${ }^{28}$

24 See id at 228-34. See SC Const Art XXVI (1776), reprinted in Francis N. Thorpe, ed, 6 The Federal and State Constitutions, Colonial Charters, and Other Organic Laws 3247 (GPO 1909) (mandating that an executive's power to wage war requires legislative consent). The inportance of the South Carolina Constitution will be addressed in the text accompanying note 87.

25 Mass Const Art VII (1780), reprinted in Francis N. Thorpe, ed, 3 The Federal and State Constitutions, Colonial Charters, and Other Organic Laws 1901 (GPO 1909). As Gordon Wood has observed, the Massachusetts constitution "came to stand for the reconsidered ideal of a 'perfect constitution"' in the minds of the Framers. Wood, Creation at 434 (cited in note 15).

26 In 1770s American political writing, Montesquieu and Locke accounted for more than 75 percent of all references to Enlightenment thinkers. Lutz, Origins of American Constitutionalism at 142 (cited in note 12). As Lutz puts it, "Montesquieu is almost without peer during the founding era" in terms of influence. Id at 144. After Montesquieu, Lutz reports, Blackstone was the second most commonly cited secular thinker and was cited two-and-a-half times as often as Locke. Id. The importance of their work on the separation of powers is discussed in W.B. Gwyn, The Meaning of the Separation of Powers (Tulane 1965). See also M.J.C. Vile, Constitutionalism and the Separation of Powers 58-130 (Liberty Fund 2d ed 1998).

27 See John Locke, The Second Treatise of Government \$\$ 143-47 (Barnes \& Noble 3d ed 1966); Montesquieu, The Spirit of the Laws 194 (D. Appleton 1900) (Thomas Nugent, trans); William Blackstone, 1 Commentaries on the Laws of England $* 244-54$ (Chicago 1979).

28 See note 26. 
To be sure, Professor Ramsey relies upon Locke and Blackstone for his notion that declaring war meant a beginning of hostilities either by "word or action." According to Professor Rainsey, Locke believed that "declaring war" meant commencing liostilities. The only evidence Ramsey offers is that The Second Treatise had observed that a state of war could be created when inen "declar[ed] by Word or Action ... a sedate setled Design, upon anotlier Man's life." ${ }^{, 29} \mathrm{He}$ considers this simgle statement to be "excellent evidence of an ordinary ... usage in whicl 'declaring' could be done by 'word or action.","

Professor Ramsey's great reliance on this passage-indeed, it is the crux of his argument-deinonstrates the problems witl his use of primary sources. The passage froin Locke does not actually use the phrase "declaring war." Ratlier, it reads:

"The state of war is a state of enmity and destruction; and therefore declaring by word or action, not a passionate and hasty, but a sedate, settled design upon anotlier man's life, puts him in a state of war with him against whom he lias declared such an intention, and so lias exposed his life to the other's power to be taken away by him, or any one that joins with him in his defence and espouses his quarrel." ${ }^{\text {sz }}$

Locke has not used the phrase "declaring war," but has instead used the phrase "declaring ... a sedate, settled design upon another man's life." Here, as Professor Raunsey himself admits, Locke is generally discussing the difference between the state of war and the state of nature, and why a inan's intention to commit inurder places him in the former. It is obvious that Locke is not referring to governinental structure or constitutional design, or even questions concerning relations between nations. Since Professor Ramsey lays the foundation of his argument on the precise meaning of "declaring war," this quote from The Second Treatise is out of place. In fact, as far as I can tell, Locke never used the phrase "declaring war" anywhere in the Second Treatise.

Professor Ramsey focuses on this rletorical use of "declaring" war while ignoring The Second Treatise's more precise discussion of war powers. For example, other passages froin The Second Treatise work out in detail the powers of the executive branch in foreign af-

29 Ramsey, $69 \mathrm{U}$ Chi L Rev at 1591 (cited in note 4), quoting John Locke, The Second Treatise of Government, in John Locke, Two Treatises of Government 265, § 16 at 278 (Cambridge 1988) (Peter Laslett, ed).

30 Id at 1592.

31 See Locke, Second Treatise at $\S 16$ (cited in note 27).

32 Id (einphasis added). 
fairs. Those sections describe a "federative power," located in the executive branch, which contains "the power of war and peace, leagues and alliances, and all the transactions with all persons and communities without the conımonwealth." ${ }^{33}$ Locke inakes clear that the federative power is "always almost united" with the executive power, and that separating the two would lead to "disorder and ruin" because matters of war and peace did not lend themselves to "direct[ion] by antecedent, standing, positive laws." " Professor Ramsey cannot explain why Locke's rhetorical use of "declaring" war in discussing a hypothetical state of nature should preempt his specific discussion of war, foreign affairs, and the separation of powers.

Professor Rainsey repeats this odd use of prinnary sources in his treatment of Blackstone. He argues that Blackstone agreed with the idea that declaring war meant commencing war, because of a passage from the Commentaries in which Blackstone says that a pirate, "by declaring war against all mankind, all mankind nust declare war against him.. ${ }^{35}$ Agam, Professor Ramsey has sought to infer a precise legal meaning of "declaring war" from what is clearly a rhetorical use of the phrase. And again, Professor Ramsey ignores other sections in the same source that specifically discuss war, foreign affairs, and the separation of powers. Like Locke, Blackstone clearly believed that the power to commence hostihties lay with the executive: "[T] he king has also the sole prerogative of making war and peace," and the king is the "generalissimo, or the first in military command, within the kingdom." $"$ Blackstone further argued that a declaration of war served as nore of a notification that the sovereign authority has decided on war, and that a state of war existed between the citizens of the warring nations. ${ }^{37}$ Nowhere does Blackstone assert, in the context of the separation of powers, that "declaring war" meant beginning war by "word or action."

33 Id at $\$ 146$.

34 Id at $\$ \$ 147-48$.

35 Ramsey, 69 U Chi L Rev at 1592 (cited in note 4), quoting William Blackstone, 4 Commentaries on the Laws of England *71 (Chicago 1979).

36 Blackstone, 1 Commentaries at $* 249,254$ (cited in note 27 ).

37 See id at 249-50 ("[I]n order to make a war completely effectual, it is necessary with us in England that it be publicly declared and duly proclaimed by the king's authority; and, then, all parts of both the contending nations ... are bound by it.").

38 Professor Raunsey's decision to relegate to footnotes Blackstone's discussion of a declaration of war illustrates the problems in his approach to the primary materials. See Ramsey, $69 \mathrm{U}$ Chi L Rev at 1584-85 n 167, 1588-89 n 176 (cited in note 4). With Locke and Montesquieu, Blackstone was one of the three most influential secular thinkers among the Framers. Blackstone in particular had great appeal to the Framers as the authoritative treatise on many areas of law. Wood, Creation at 10 (cited in note 15). His discourses on the separation of powers and the war power were quite familiar to the Framers; indeed, Alexander Hamilton's definition of the King's 
Finally, while he struggles to show that Vattel and Bynkershoek's use of "declaring war" was consistent with his theory, Professor Ramsey pays no heed to the most influential of all writers on the separation of powers, Montesquieu. ${ }^{39}$ In his Spirit of Laws, Montesquieu located the foreign affairs power and, specifically, the war power in the executive. "By the [executive power, the king] makes peace or war, sends or receives einbassies, establishes the public security, and provides agamst invasions.. ${ }^{40}$ Montesquieu beheved that the British legislature possessed all the control it needed over the executive's war powers, because of its authority to terminate military funding and even to disband armies. ${ }^{41}$ Montesquieu clearly uses "making war" to mean the commencement of hostilities. Montesquieu never even mentions "declaring war." Professor Ramsey's reliance on rhetoric by Locke and Blackstone not only misreads those writers, but it also ignores their significant agreement with Montesquieu. Properly read, all three anthorities agreed that (a) the execntive possessed the power to start hostilities, which they described as the power to "make" (not declare) war, and (b) the legislature enjoyed an important check on ex-

war powers seems to derive directly from Blackstone. See Federalist 69 (Hamilton), im Clinton Rossiter, ed, The Federalist Papers 415-23 (Mentor 1961) (citing Blackstone for the proposition that "the prerogative of making treaties exist[ed] in the crown in its utunost plenitude" and noting that the king liad the further power of "declaring war, and of raising and regulating fleets and armies by his own authority"). Blackstone's thinking about declarations of war, we may assume, lield far nore significance to the Framers than the works of Rutherforth and Hale, who were never cited or discussed in the political literature and debates of the ratification. Blackstone laad this to say about declarations of war:

[W] liy according to the law of nations a denunciation of war ouglt always to precede the actual commencement of lostilities, is not so much that the eneny may be put upon his guard, (whicl is matter rather of magnanimity than right) but that it may be certainly clear that the war is not undertaken by private persons, but by the will of the whole community; whose right of willing is in this case transferred to the supreme magistrate by the fundamental laws of society. So that, in order to make a war completely effectual, it is necessary with us in England that it be publicly declared and duly proclaimed by the king's authority; and, then, all parts of both the contending nations, from the highest to the lowest, are bound by it.

Blackstone, 1 Commentaries at 249-50 (cited in note 27). Somelow, Professor Ramsey reads this language-which is clearly borrowed from Grotius-as "highly anbiguous." Ramsey, $69 \mathrm{U}$ Chi L Rev at 1584-85 n 167 (cited in note 4). To the contrary, it seems that Blackstone believed that a declaration served the purpose of notification that hostile actious were legal because authorized by the sovereign. In any event, Blackstone certainly does not discuss a declaration as in any way necessary for doinestic constitutional purposes.

39 Montesquieu easily outpaced all other writers in his influence on the Framers' thinking about the separation of powers. Lutz, Origins of American Constitutionalism at 144 (cited in note 12). The writers of The Federalist Papers, for example, sometimes quoted long passages from Montesquieu's Spirit of the Laws. See, for example, Federalist 9 (Hamilton), in Rossiter, ed, Federalist Papers at 74-75 (cited in note 38)

40 Montesquieu, Spirit of Laws at 182 (cited in note 27).

41 See id at 193-94. 
ecutive warmaking through its power over appropriations. We should take such agreement seriously in interpreting the Constitution, as Montesquieu, Locke, and Blackstone were the three most influential authorities on the separation of powers and constitutional design of their time. Professor Ramsey's failure to consider Montesquieu reveals an incomplete historical analysis, in addition to a focus on rhetorical language at the expense of the core historical and constitutional developinents of the period.

These three historical developments - the pattern of British practice, the experience under the state constitutions, and the work of constitutional theorists - set the stage for ratification. All three sources indicate that the Frainers would have understood the President's powers as coinmander-in-chief and chief executive as vesting him with the authority to initiate and conduct hostilities. They demonstrate that the power to declare war would not have been understood by the Framers as a significant restriction on the President's powers in war. Instead, the relevant history points to the control over money as the legislature's most effective check on the executive branch. It is this historical backdrop, rather than Professor Ramsey's effort to draw distinctions among eighteenth-century legal writers, that provides the relevant context for the ratification of the Constitution.

42 Professor Ramsey's approach is even incomplete on its own terms. He seeks to develop a rhetorical, nonlegal meaning of "declare" as used in the eighteenth century, and for that reason turns to Locke, Blackstone, and others. Unfortunately, however, he does not adequately examine how the Framers theniselves used the word "declare" at the sanie level of generality and in the saine contexts in which he exammed the discussions of British and international commentators. I briefly review the Framers' use of "declare" in Part II.C, but an example here may help to highlight the slortcomings in Ramsey's analysis. On August 17, 1787, the Federal Convention discussed Congress's power to "define and punish Piracies and Felonies committed on the high Seas, and Offenses against the Law of Nations." US Const Art I, § 8. As originally drafted, the clause lad given Congress the power to "declare the law and punishment of piracies and felonies." Max Farrand, ed, 2 The Records of the Federal Convention of 1787315 (Yale 1937) (emphasis added). Edmund Randolph "doubted only the efficacy of the word 'declare," id, and he and James Madison noved to replace it with "define." Id at 316. It appears that Madison believed that the power to declare existing felonies at common law would be difficult because such crimes were "vague" and subject to competmg niterpretations by the states. See id. The Convention adopted Madison and Randolph's amendment unanimously. See id. Thus, the delegates apparently thought the power to "declare" the law and punishment of piracy and offenses against the law of nations was limited only to expressing the existing state of the law, so nuch so that they vested in Congress the broader power to "define" such crimes. This discussion is especially revealing because it occurred on the same day as the Convention's quick decision to change Congress's power from "make" to "declare" war. Id at 318-19. What is troubling about Professor Ranisey's analysis is that he never undertakes the same review of the most directly relevant source-the Framers' use of the word "declare" - that he attempts to provide with the British and international sources. As a result, Professor Ransey's approach bears the strange feature of privileging the word choice of foreign writers above the thinking of the Framers theinselves. 


\section{Understanding the Original Understanding}

These discrete flaws are syinptoinatic of Textualism and War Powers's deeper problem: It lacks a consistent approach to interpretation. Professor Ramsey does not identify what aspects of the original understanding are important, what moments in the revolutionary or ratification periods are critical, or what types of evidence are nore relevant than others. A more nuanced view of originahsm recognizes that the understandings of the state ratifying conventions are of primary importance, because it was their approval that brought the Constitution into force as a legal and pohtical matter. ${ }^{43}$ The intellectual history of the period is important only insofar as it helps us recreate what the Constitution's ratifiers thought the text that they ratified meant. Even though certain ideas, definitions, and concepts unght have been present in the intellectual world of the eighteenth century, they are not relevant to the original understanding unless they were known to, and understood by, the Framers who ratified the Constitution.

One of Professor Raunsey's difficulties is that he cannot draw connectious between his evidence-the rhetorical usage of the phrase "declaring war" in some eighteenth-century sources-with the actual

43 See Rakove, Original Meanings at 9 (cited in note 15) ("[T]he authority of the Constitution as supreme law rests on its ratification by the special, popularly elected conventions of 1787-88."); Leonard Levy, Original Intent and the Framers' Constitution 1-29 (Macmillan 1988) (examining and interpreting the arguments unade during the ratifying conventions); Charles $A$. Lofgren, The Original Understanding of Original Intent?, 5 Const Commentary 77,111-13 (1988) ("[I]t is not too much to say that at least some of the founders saw the ratifiers' historical or subjective mtent as a check on constructions which cut loose from the original understandings of the sovereign people.").

This view of the primacy of the state ratification conventions was shared by several of the leadimg Frauners. As James Madison argned during the 1794 Jay Treaty debates, when the draft Constitution "came from [the Philadelphia convention] it was nothing more than the draft of a plan, nothing but a dead letter, until life and validity were breathed into it by the voice of the people, speaking through the several State Conventions." 5 Annals of Congress 776 (Gales and Seaton 1849). On this point, Madison was repeating the view he had expressed as Publius during the ratification struggle itself. See Federahist 40 (Madison), in Rossiter, ed, Federalist Papers at 252 (cited in note 38) (arguing that the Constitution was "of no more consequence that the paper on which it is written, unless it be stamped with the approbation of those to whoon it is addressed."). James Wilson inade the saine argument about the primacy of the ratifying conventions over the constitutional convention as well. See Merrill Jensen, ed, 2 Documentary History of the Ratification of the Constitution 483-84 (State Historical Society of Wisconsin 1976) (statement in Pennsylvauria ratifying convention).

Professor Ramsey does not appear to place any great weight in the Philadelphia Convention's decision to change Congress's power from "make war" to "declare war." Farrand, ed, 2 Records 318-19 (cited in note 42). I agree with Professor Ramsey lere, not ouly because Madison's brief (and secret) notes of this decision seem garbled, but also because the Federal Convention itself exercised no power other than that of making recommendations. As the Framers themselves understood, it was the ratifying conventions that gave the Constitution its political legitimacy, not the proceedings of the Philadelphia convention. See, for example, Yoo, 99 Colum L Rev at 2025-26 n 328 (cited in note 16). 
events of the ratification. Nevertheless, he claims that the Framers transformed a certain understanding of a nation's power to declare war under international law-one that he admits is not all that clear and distinct from the one I have identified in earher work-imto an element of the separation of powers. Professor Rainsey does not undertake the difficult project of explaining how a power relevant for purposes of international law metamorphosed into a critical check by which Congress could control the war powers of the President. Nor does Professor Ramsey examine the development of the separation of powers and of the foreign affairs power during the ratification, which ought to occupy the core of any account of the original understanding of the war power.

As a result, Professor Ramsey's account of the ratification is disappointing. He seems unaware of the course of ratification $m$ the different state conventions, of the central disputes that arose between Federalists and Anti-Federalists, and of the pohtical forces at work in the states or in the nation as a whole. In only a cursory review, Professor Ramsey examines the few mentions of declarations of war during the ratification to show the Framers' use of the phrase does not clearly foreclose his thesis." He has not shown, however, that any of these examples demonstrate that the Framers understood "declaring war" to mean specifically commencing or engaging im hostilities, as no Framer apparently ever described the power in that fashion. All Professor Ramsey is left with are a few Federalist claims that the new President would not be a despot, because the Constitution transferred to Congress several of the king's powers, such as that of declaring war and of raising armies. ${ }^{45}$ In none of these exchanges did the Federalists explain what "declaring war" meant; they only included it in a general enumeration of Congress's powers.

By contrast, there was an important moment in the ratifying convention when the precise issue-whether Congress could prevent a President from unilateral warmaking - was jomed. It was not raised im an obscure, garbled, last-minute debate (as was the drafting of the Declare War Clause during the Philadelphia Convention), or an unread Anti-Federalist paper. Rather, the question was directly raised and an-

44 See Ramsey, 69 U Chi L Rev at 1602-06 (cited in note 4).

45 See generally Federalist 69 (Hamilton) at 415-23 (cited in note 38) (indicating that the President is significantly less powerful than the King of Great Britain and that Congress is granted power over declaring war and raising armies); Jonathan Elliot, ed, 4 The Debates in the Several State Conventions on the Adoption of the Federal Constitution 107 (2d ed 1836) (speech of James Iredell before the North Carolina ratifying convention) ("The President has not the power of declaring war by his own authority, nor that of raising fleets and armies. These powers are vested in other hands."). 
swered in the ratifying convention of the most important state in the Union. Virginia was the critical state for ratification. ${ }^{45}$ Virginia also recommends itself because, froin the records that survive, it appears that the state experienced the fullest, and most contested, debate over the Constitution. Anti-Federalists brought forth their greatest leaders, such as Patrick Henry, George Mason, and Edınund Randolph, to do battle with Federalist leaders such as George Washington, James Madison, and John Marshall. ${ }^{47}$ Virginia was also the toughest hurdle that the Constitution surmounted ou the way to ratification; an AntiFederahist motion to send the Constitution back for amendment lost by only 88 to $80 .^{43}$ Virginia, therefore, should be of decisive iniportance in interpreting the Constitution because it was a critical "vetogate" through which the Constitution had to pass before becoming law.

Iu this nost critical of ratification conventious, Anti-Federalists waged a direct attack on the Constitution's allocation of war powers. Anti-Federahists clainied that the states would have no means to control the national government's ability to make war, and they further argued that the Constitution would not preveut the President from becoming a military despot. ${ }^{50}$ Patrick Henry argued before the Virginia convention:

If your American chief, be a man of ambition, and abilities, how easy is it for hin to render himself absolute! The army is in his hands, and, if he be a man of address, it will be attached to him; and it will be the subject of loug meditation with him to seize the

46 Geographically, Virginia linked the North and South, and its political importance was such that leading Federahists believed that the Constitution would never survive without her approval. See Bernard Bailyn, ed, 2 Debate on the Constitution 1067 (Library of America 1993) ("[B]oth Federalists and Antifederalists anticipate that a union without Virginia and New York will be impracticable."); Forrest McDonald, We the People: The Economic Origins of the Constitution 255-56 (Chicago 1958) (noting the importance of Virginia to ratification). Although wlien the Virginia Convention began only eight states had ratified the Constitution, by the time it ratified the Constitution it was the tenth state to do so. Nonetheless, both conteniporaneous observers and modern-day historians agree that the Union could not have survived without Virginia's agreenent to the Constitution. See id.

47 See Lance Banning, Virginia: Sectionalism and the General Good, in Michael A. Gillespie and Micliael Lienesch, eds, Ratifying the Constitution 261-99 (Kansas 1989) (describing circumstances of Virgima ratifying convention).

48 John P. Kaminski and Gaspare J. Saladino, eds, 10 The Documentary History of the Ratification of the Constitution 1538 (State Historical Society of Wisconsin 1993) (vote of Jime 25, 1788).

49 See Wilham N. Eskridge, Jr., Philip P. Frickey, and Elizabeth Garrett, Cases and Materials on Legislation: Statutes and the Creation of Public Policy 66-67 (West 3d ed 2001) (defining and discussing vetogates).

50 Under the Articles of Confederation, the states controlled the sources of supply and money for the national government, which allowed the states to prevent any actions with which they disagreed. See generally Federalist 11-13 (Hamilton), in Rossiter, ed, Federalist Papers at 84-99 (cited in note 38). 
first auspicious moment to accomplisl his design .... If we make a King, we inay prescribe the rules by which he sliall rule his people, and imterpose such checks as shall prevent him from infringing them: But the President, in the field, at the head of his army, can prescribe the terms on which lie sliall reign master, so far that it will puzzle any American ever to get his neck from under the galling yoke.... If ever lie violates the laws ... [li]e [inay] coine at the liead of his army to carry every thing before him .... [W] here is the existing force to punisl him? Can lie not at the lead of his army beat down every opposition? Away witl your President, we sliall have a King: The army will salute him Monarch; your militia will leave you and assist in making him King, and fight against you: And what have you to oppose this force? What will then become of you and your riglits? Will not absolute despotism ensue?

To eliminate the specter of executive tyranny, Anti-Federalists wanted to restore the funding power to the states, ban standing armies in peacetime, and return control over the militias to the states. ${ }^{52}$ In other words, it was not enougl that the purse and sword would be in separate liands-Anti-Federalists wanted the purse and sword to be im different governinents.

In response, Federalists never described Congress's power to declare war as a clieck on the President, even though it was very mucli im their interest to do so. Rather, they relied upon the traditional legislative clieck on executive warmaking estabhished by Congress's control over funding. This created a double security against tyranny. First, the federal government's power to make war itself would be divided, and, second, Congress would liave a powerful means of controlling presidential military adventurism. Replied Federalist George Niclıolas:

Under the new Government, no appropriation of money, to the use of raising or supporting an army, sliall be for a longer term than two years. The President is to command. But the regulation of the army and navy is given to Congress. Our representatives will be a powerful check liere. The influence of the Commons im England in this case is very predominant. ${ }^{\text {s3 }}$

In otlıer words, the warmaking relationslip between President and Congress would operate just as did the one between Crown and

51 John P. Kaminski and Gaspare J. Saladino, eds, 9 Documentary History of the Ratification of the Constitution 964 (State Historical Society of Wisconsin 1990) (speech of June 5, 1788).

52 See Kaminski and Saladino, eds, 10 Documentary History at 1554 (cited in note 48) (proposed amendinents reported out June 27, 1788).

53 Id at 1281 (speech of June 14,1788). 
Parliament. It is significant that Anti-Federalists did not disagree about the workings of the Britisl system. They appear only to have believed that the conspiring branches of the federal government would combime these powers to oppress the states.

Madison, as the leader of the drive for ratification in Virginia, followed with a powerful rejection of the Anti-Federalist critique. Madison criticized Henry's view that the purse and sword liad to be held by different governments (in other words, the states and the national). He explicitly analogized to the British experience:

What is the meaning of this maxim? Does it mean that the sword and purse ought not to be trusted in the hands of the same Government? This cannot be the meaning. For there never was, and I can say there never will be, an efficient Government, in which both are not vested. The only rational ineaning, is, that the sword and purse are not to be given to the same nember. Apply it to the British Government, which has been mentioned. The sword is in the hands of the British King. The purse in the hands of the Parliament. It is so in America, as far as any analogy can exist. ${ }^{54}$

Like Nicholas, Madison never invoked Congress's power to declare war as a legislative check on the executive. Rather, in order to deflect accusations that the executive branch would remain nncontrolled, he rehed directly upon Congress's control over funding. $\mathrm{He}$ even predicted that Congress's powers over warmaking would operate in a manner identical to those of Parliament.

Madison further emphasized that the funding power, in addition to Congress's other powers over the military, would prove to be more than enough of a check on the President.

The purse is in the hands of the Representatives of the people. They have the appropriation of all inomies. They have the direction and regulation of land and naval forces. They are to provide for calling forth the militia-And the President is to have the command; and, in conjunction with the Senate, to appoint the officers.

It is inportant to notice what Madison did not argue. Madison did not assert that the Declare War Clause wonld check presidential power. Nor did he claim that the Constitution imposed specific and formal rules for the warmaking process, as it did for the legislative process. Instead, Madison argued that the branches wonld develop their war policies through the conflict or cooperation of their plenary

54 Id at 1282 (speech of June 14, 1788).

55 Id. 
constitutional powers. He emphasized Congress's power over funding and over the military, not the power to declare war.

Together, Federalists and Anti-Federahists in Virginia engaged in a debate over the war power, and the understanding that emerged followed traditional Anglo-American practice. As commander-m-chief, the President would have the initiative im matters of war, but Congress could use its appropriations power to enforce its own policies. Nowhere in this critical debate, which represents the most direct exchange of views over war powers between Federahists and AntiFederalists, does the power to declare war make an appearance. As Virginia was the critical state im the process of ratification, this evidence directly reflects the original understanding of war powers held by those who ratified the Constitution. These exclianges serve as the nost authoritative historical source for imterpreting the war power, because they record the public explanation of the Constitution's ineaming that won its ratification.

Professor Ramsey never explains, nor even takes note of, the Virginia ratifying convention. This slows the core fault in his methodology. To be sure, he has identified some examples in which some eighteenth-century writers appeared to use the phrase "declare war" to mean commence war. Professor Ramsey's effort, however, to prove that the Framers' understanding of the plirase was not imconsistent with these rhetorical uses of "declare war" does not present a coherent historical account of the development of the war power. Unfortunately, Professor Ramsey's approach ignores the richness of the liistorical context and the iniportance of the political decisions and explanations made by the Framers themselves. A more comprehensive theory, which I lave undertaken earher and have only summarized here, shows that the Framers did not beheve they lad established a strict, legalistic process for warmaking. Instead, they expected that the branches would use their plenary constitutional powers to either cooperate or contest for primacy over war.

\section{Fighting the Constitutional TeXT}

That said, I agree with the central tenet of Textualism and War Powers that we should interpret the Constitution based on the meaning of its words as understood by its ratifiers. Professor Ramsey says that this methodology "gives mucl more primacy to the actual words of the Constitution, and accords much less iniportance to extrapolations from statements (particularly after-the-fact statements) of the 
generalized outlook of individual Frainers." ${ }^{56}$ Unfortunately, I am afraid that Professor Ramsey has failed to satisfy his own standards. He has not given his attention to the Constitution's actual text and structure, and instead he has sought to "extrapolate," from a few quotations, a shared original understanding. Yet, his historical account conceals a simple textual argument long inade by pro-Congress scholars. He beheves that the power to declare war must mean soinething more than what its text suggests, and that something inust be the sole authority to commence hostilities.

In this and the following Part, I explain why the text and structure of the Constitution cannot support this reading. First, I should make clear the core of Professor Ramsey's textual arguinent and its imphications. As I understand it, Professor Ransey beheves that the Constitution sets out a single process for waging war. As others have argued before, Professor Ramsey beheves that the Framers understood the Declare War Clause as giving Congress the sole power to decide on whether to commence military hostilities against other nations." Under international and domestic law at the time, therefore, "declare war" meant "begin war" or "commence war" or "authorize war." Only once Congress had issued this authorization could the President trigger his commander-in-chief authority and fight the war to its conclusion.

Professor Ramsey's position simply finds hittle support in the constitutional text and structure. Professor Ramsey's textual problems are threefold. First, he defines the President's commander-in-chief and executive powers only as the residue of the Declare War Clause, rather than as independent grants of authority. Upon closer exammation, however, it seems clear that these authorities provide the President with the imitiative and leadership in war, including the power to commence hostilities. Second, Professor Ramsey ignores important provisions in the Constitution itself, and in other founding documents, that demonstrate that the Declare War Clause does not include the exclusive power to initiate hostilities. These provisions, such as Article I, Section 10 of the Constitution, which bars states from "engag[ing] im War" without congressional consent, show that when the Framers wanted to require legislative pre-approval of hostilities, they knew how to do it. ${ }^{3 s}$ Third, the pro-Congress view of war powers runs counter to the deeper structure of the Constitution and the nature of

56 Ramsey, 69 U Chi L Rev at 1554 (cited in note 4).

57 Ramsey and I agree, as do most commentators on the subject, that if the Uinted States suffers an attack, no declaration of war is necessary.

58 US Const Art I, § 10. 
the executive power. This Part will take up the job of analyzing the textual and structural basis for the allocation of war powers.

\section{A. Practice and the Commander-in-Chief}

Professor Ramsey's textual argument is a relatively simple one. Because declarations of war do not matter much, the power to declare war must be broader than its terms suggest. In fact, it inust mclude the sole power to coinmence military hostilities because otherwise it would be meaningless. Professor Ramsey mistakenly believes that a textualist approach allows the Declare War Clause to be read in isolation. One of the most serious shortcomings of Textualism and War Powers is its failure to address otlier constitutional provisions that directly involve the making of war. Instead of turning immediately to eighteenth-century legal commentary, a textualist interpreter of war powers ought first to consider the import of the vesting of all executive power in the President, the Commander-m-Chief Clause, Article I, Section 10's prolibition on state warmaking, Article III's definition of treason, and Congress's powers over the raising and supporting of arimes. Placing the Declare War Clause in its textual context shows that the Constitution does not define a legahistic procedure for warmaking, but instead creates a flexible system that permits different variations to be created through the interaction of the political branches.

While Congress has the power to declare war, the President also possesses significant war powers, ones that Professor Ransey does not address witl the same attention that he brings to the Declare War Clause. Article II, Section 2 of the Constitution states that the "President shall be Commander in Chief of the Army and Navy of the United States, and of the Militia of the several States, when called into the actual Service of the United States." ${ }^{\text {"s9 }} \mathrm{He}$ is further vested with all of "the executive Power" and the duty to execute the laws. ${ }^{60}$ These provisions have long been recognized to give the President absolute command over the armed forces of the United States, to the point of ordering their use in hostilities abroad. Nowhere does the constitutional text provide that the commander-in-chief power cannot be used by the President to wage military hostilities unless Congress first issues a declaration of war. Professor Ransey never examines the original meaning of the Commander-in-Chief Clause, but ratler inerely assumes that the Declare War Clause inust soinehow trump the Cominander-in-Chief Clause, and then devotes some afterthought to defin-

59 US Const Art II, § 2, cl 1.

60 US Const Art II, $\$ 1$, cl 1; US Const Art II, $\$ 3$. 
ing the scope of the executive's power by the afterglow of the Declare War Clause.

Professor Rainsey's neglect of the President's textual powers under Article II amounts to a fatal flaw. As practice shows, many have interpreted these provisions to allow the President to deploy military forces and to use thein both to protect the national security and to advance American foreign policy interests. The historical record shows that Congress has declared war only five times, the most recent one nore than fifty years ago in World War II. ${ }^{61}$ Meanwhile, presidents have committed military forces to combat without a declaration of war at least 125 times in the Constitution's 210-year history. ${ }^{62}$ Since World War II, moreover, presidents have engaged in several significant military engagements without a declaration of war or other congressional authorization. When President Truman introduced American troops into Korea im 1950, he did not seek congressional authorization, relying imstead on his inherent executive and commander-inchief powers. ${ }^{63}$ In the Vietnain conflict, President Johnson never obtained a declaration of war nor an unambiguous congressional authorization, although the Gulf of Tonkin Resolution expressed some level of congressional support for military intervention. ${ }^{64}$ Congress,

61 The other four were the War of 1812, the Mexican-American War of 1848, the SpanishAmerican War of 1898 , and World War I.

62 See Congressional Research Service, Instances of Use of United States Armed Forces Abroad, 1798-1989, reprinted in Thoinas M. Franck and Michael J. Glennon, Foreign Relations and National Security Law 650 (West 2d ed 1993) (histing 215 instances in which the United States has used military forces abroad and noting that, in many of those instances, the actions were conducted "solely under the President's powers as Chief Executive or Commander in Chief'); Office of the Legal Adviser, United States Departinent of State, The Legality of United States Participation in the Defense of Vietnam (March 4, 1966), in Richard A. Falk, ed, 1 The Vietnam War and International Law 583, 597 (Princeton 1968) (noting that there have been at least 125 instances il which the President has activated the armed forces withont congressional authorization). Critics argue, however, that most of these interventions either were sinall-scale operations or received sone form of congressional approval.

63 See Yoo, 84 Cal L Rev at 178-79 (cited in note 1).

64 While presidential critics such as Ely and Henkin generally attack unilateral executive warmaking in the postwar period, they find the Gulf of Tonkin Resolution to amount to acceptable congressional authorization for war, even though it was not a declaration of war. See Ely, War and Responsibility at 16 (cited ni note 2) (claiming that the Resolution "certainly was broad enough to authorize the subsequent actions President Johnson took in Vietnan"); Henkin, Constitutionalism at 84 (cited in note 2) ("In my view, Congress had in fact authorized [the Vietnam War] in the Tonkin Gulf Resolution and the war was therefore within the President's authority delegated to him by Congress."). Other critics, however, beheve the Vietnan1 War was unconstitutional as well. See, for exanıle, J. Gregory Sidak, To Declare War, 41 Duke L J 27,70-71 (1991) (arguing that Congress shirked its responsibilities by failing to obey constitutional formahties with regard to the Vietnam conflict); Arthur M. Schlesinger, Jr., The Imperial Presidency 180 (Houghton Mifflin 1989) (stating that a resolution, such as the Tonkin Gulf Resolution, "giving the President authority to use force as he saw fit in vague future contingencies was precisely the sort of resolution rejected as nnacceptable in the early repubhi"); Francis D. Wormuth, The 
however, never authorized the expansion of the Vietnam War into Laos and Cambodia by President Nixon. ${ }^{65}$

To be sure, in the wake of Vietnam, Congress enacted the War Powers Resolution, which places time limits and reporting requirements on the use of Ainerican military force abroad. ${ }^{66}$ Presidents, however, have refused to acknowledge its legality, and neither Congress nor the courts have shown any interest in enforcing it. Presidents Ford, Carter, and Reagan, for example, engaged in several military actions without congressional assent, although they did submit reports that were consistent (while disclaiming compliance) with the requirements of the Resolution. ${ }^{67}$ Publicly declaring that he had the constitutional authority to initiate war unilaterally, President Bush committed a half-miltion soldiers to warfare in Operation Desert Storm for a period of time that violated the War Powers Resolution. ${ }^{6 s}$ President Clinton followed these precedents with interventions in Somaha, Haiti, Bosnia, the Middle East, and, most significantly, Kosovo, none of which were authorized by Congress. ${ }^{69}$

Practice plays an important interpretive role for the question of the proper allocation of war powers. Both the Supreme Court and the political branches have often recognized that governınental practice represents a significant factor in establishing the contours of the constitutional separation of powers. ${ }^{70}$ Further, the role of practice in understanding the constitutional text is heightened in the foreign affairs and national security areas, where an absence of judicial precedent requires us to examine for authority the long history of mterbranch in-

Nixon Theory of the War Power: A Critique, 60 Cal L Rev 623,690-94 (1972) ("[S]ince the Tonkin Gulf Resolution did not elect either general or limited war and did not authorize the President to define our legal status, we were in a position that had no legal characterization, except, of course, illegality.").

65 See generally John Hart Ely, The American War in Indochina, Part II: The Unconstitutionality of the War They Didn't Tell Us About, 42 Stan L Rev 1093 (1990).

66 War Powers Resolution, Pub L No 93-148, 87 Stat 555 (1973), codified at 50 USC $\S \S$ 1541-48 (1994).

67 Yoo, 84 Cal L Rev at 181-82 (cited in note 1).

68 See id at 186-88 (describing the interaction of the President with Congress and the courts during the Gulf crisis).

69 See Yoo, $148 \mathrm{U} \mathrm{Pa} \mathrm{L} \mathrm{Rev} \mathrm{at} \mathrm{1678-83} \mathrm{(cited} \mathrm{in} \mathrm{note} \mathrm{1)} \mathrm{(describing} \mathrm{the} \mathrm{lack} \mathrm{of} \mathrm{congres-}$ sional authorization for the use of American troops in Kosovo).

70 See, for example, Mistretta v United States, 488 US 361, 393 (1989) (recognizing the significance of understanding practical consequences when determining the placement of commissions within the federal government); Youngstown Sheet \& Tube v Sawyer, 343 US 579, 637 (1952) (Jackson coucurring) ("[C]ongressional inertia, imdifference or quiescence may sometimes, at least as a practical matter, enable, if not invite, measures on independent presidential responsibihty."); United States v Midwest Oil Co, 236 US 459, 474 (1915) (noting that a "longcontinued practice, known to and acquiesced in by Congress" creates a presumption that the practice is legitimate). 
terpretation and interaction. ${ }^{71}$ Finally, practice shows that many government leaders throughout Ainerican history have read the constitutional text as providing presidents with the power to commence military hostilities without congressional authorization.

Practice demonstrates that the political branches have read the constitutional text to establish a stable, working system of war powers. The President has taken the primary role in deciding when and how to initiate liostilities. Congress has allowed the executive branch to assume the leadership and initiative in war, and instead has assumed the role of approving military actions after the fact by declarations of support and by appropriations. ${ }^{2}$ As I will describe below, this practical reading of the text is consistent with the original understanding of the commander-in-chief and executive powers held during the period leading up to the Constitution's ratification. ${ }^{73}$ Throughout American history, courts have agreed that these powers give the President broad constitutional authority to use military force in response to threats to the national security and foreign policy of the Umited States. ${ }^{74}$

In light of Article II's text, I have argued that the Constitution constructs a loose framework within which the President as comnander-in-chief enjoys substantial discretion and initiative in conducting military hostilities. At the same time, Congress plays a significant role by controlling both the resources for war (through funding) and the legal status of hostilities (through declaring war). Unlike the legislative process, the constitutional text here clearly does not establisl a

71 See Robert J. Delahunty and John C. Yoo, The President's Constitutional Authority to Conduct Military Operations against Terrorist Organizations and the Nations that Harbor or Support Them, 25 Harv J L \& Pub Pol 487, 503 (2002).

72 See Koh, National Security Constitution at 123-33 (cited in note 2) (describing and criticizing Congress's role during recent military interventions).

73 See Yoo, 84 Cal L Rev at 196-241 (cited in note 1) (describing the attitudes in Britain and the colonies towards the allocation of war powers).

74 See Loving $v$ United States, 517 US 748, 776 (1996) (Scalia concurring in part and concurring in judgunent) (stating that the "inherent powers" of the commander-in-chief "are clearly extensive"); Johnson v Eisentrager, 339 US 763, 789 (1950) (noting that it is not the role of the judiciary to entertain suits that challenge the President's authority to deploy United States armed forces "abroad or to any particular region"); The Prize Cases, 67 US (2 Black) 635, 670 (1862) (whether the President "in fulfilling his duties as Commander in Chief" had met with a situation justifying treating the southern States as belligerents and instituting a blockade, was a question "to be decided by him" and which the Court could not question, but must leave "to the political department of the Government to which this power was entrusted"); Fleming $v$ Page, 50 US (9 How) 603,614 (1850) ("As commander-m-chief, [the President] is authorized to direct the movements of the naval and military forces placed by law at his command, and to einploy them in the manner he may deem most effectual."); Massachusetts v Laird, 451 F2d 26, 32 (1st Cir 1971) (noting that the President has "power as Commander-in-Chief to station forces abroad"). See also William P. Barr, Authority to Use United States Military Forces in Somalia, in 16 Op Off Legal Counsel 6 (1992) (noting the President has the authority to commit troops to "protect Somahans and other foreign nationals in Somalia"). 
specific procedure for going to war. Rather, it allocates different, potentially conflicting war powers to the two branches. Professor Rainsey cannot deinonstrate that the constitutional text compels the sort of sinooth, legahistic process upon the exercise of the commander-inchief and executive powers that he proposes. Indeed, when heeding the better angels of his nature, Ransey has recognized that Article II's unenumerated grant of powers requires that foreign affairs powers generally be understood as vested in the President, and that any anbiguities in the allocation of powers involving international relations must be construed in favor of the executive branch. ${ }^{75}$

\section{B. Declaring War and Congressional Consent}

Professor Ramsey presumably does not grapple with the executive's textual war powers because he assumes that the meaning of the Declare War Clause is utterly clear. Professor Ramsey has reached this conclusion, however, without examining the text of Declare War Clause itself. The Constitution nowhere defines or uses the phrase "declare" in the manner suggested by Professor Rainsey. If he were correct, we should expect the Framers to have repeated the phrase elsewhere in the Constitution when addressing the same subject. The Framers, however, chose otherwise.

When discussing war in other contexts, the Constitution einploys phrases that indicate that declaring war referred to soinething less than the sole power to send the nation into hostilities. In Article I, Section 10, for example, the Constitution declares that states may not "engage" in war. ${ }^{76}$ Granting Congress the sole authority to "engage" the nation in war would have been a inuch clearer, direct method for vesting in Congress the power to control the actual conduct of war. To take another example, Article III of the Constitution defines the crime of treason, in part, as consisting of "levying War" against the Uinted States." Again, "levying" appears to be broader in meaning than merely declaring. If the Frainers had used "levy War" in Article I, Section 8 , they certainly would have made far clearer their alleged intention to grant Congress the sole power to decide whether to send the United States to war against another country.

Article I, Section 10 deals the most direct blow to Professor Ramsey's textuahist reading. It states:

75 See Saikrishna B. Prakash and Michael D. Ramsey, The Executive Power over Foreign Affairs, 111 Yale L J 231, 252-53 (2001) ("[T]he starting point is that foreign affairs powers are presidential ... froin the ordinary eighteenth-century meaning of executive power.").

76 US Const Art I, $\$ 10, \mathrm{cl} 3$.

77 US Const Art Ill, $\$ 3, \mathrm{cl} 1$. 
No State shall, without the Consent of Congress, lay any Duty of Tonnage, keep Troops, or Ships of War in time of Peace, enter into any Agreeinent or Coinpact with another State, or with a foreign power, or engage in War, unless actually invaded, or in such imminent Danger as will not admit of delay.

This provision creates exactly the war powers process, between Congress and the States, that Professor Ramsey wants to create between Congress and the President. It even includes an exception for defending agamst sudden attacks, which Professor Ramsey and others have read into the Declare War Clause to make their theory workable. Professor Ramsey does not even attempt to account for the difference in language between Article I, Section 8 and Article I, Section 10.

If textuahsts assume that specific texts have specific meanings, they also must beheve that different texts should be interpreted to have different meanings. If the pro-Congress reading were correct, the Framers naturally would have written a provision stating that "the President inay not, without the Consent of Congress, engage in War, unless the United States are actually invaded, or in such imminent Danger as will not admit of delay." Or, Article I, Section 10 should have said "No state shall, without the consent of Congress, declare war." Instead, the Constitution only allocates to Congress the declarewar power and to the President the commander-in-chief power, without specifically stating - as it does in Article I, Section 10 with regard to the states-how those powers are to interact. The Constitution's creation of a specific, detailed war powers process at the state level, but its silence at the federal level, denıonstrates that the Constitution does not establish any specific procedure for going to war. ${ }^{79}$

Two additional textual clues support an nnderstanding of "declare war" as a ineans of recognizing the legal status of hostile acts, rather than as a necessary authorization for hostilities. Congress's power to declare war does not stand alone, but instead is part of a clause that mcludes the power to "grant Letters of Marque and Repri-

78 US Const Art I, § 10, cl 3 (emphasis added).

79 Article I, Section 10 prohibits the states from making any "agreement or compact" with a foreign power. US Const Art I, $\S 10, \mathrm{cl} 3$. In arguing that the President has the authority to make sole executive agreements, Professor Ramsey has claimed that this bar on the states implies that the Constitution recognizes certain forms of non-treaty international agreements that are not prohibited to the federal government. See Micliael D. Ramsey, Executive Agreements and the (Non)Treaty Power, 77 NC L Rev 133, 162-63 (1998). In reaching this conclusion, Professor Ramsey agrees with Myres S. McDougal and Asher Lans, Treaties and Congressional-Executive or Presidential Agreements: Interchangeable Instruments of National Policy: I, 54 Yale L J 181, 205 (1945) (describing agreements that relied upon the President's independent powers). It is puzzling that Professor Ramsey would rely on Article I, Section 10 in earher work and yet ignore it here. 
sal" and to "make Rules concernmg Captures on Land and Water.", Placement of the power to declare war alongside these other two is significant, because they clearly involved the power of Congress to recognize or declare the legal status and consequences of certaim wartime actions, and not the power to authorize those actions. Letters of marque and reprisal allowed a sovereign nation to extend the protections of the laws of war to private forces acting in coordmation with its armed forces. ${ }^{81}$ Rules concerning captures determine the law that applies to prizes seized by American forces. In both cases, these powers did not act to authorize hostilities as much as they determined the legal status and consequences of those hostilities. Understood in this way, adding the power to declare war to these other two im Article I, Section 8 makes perfect sense.

Second, other foundational documents of the period demonstrate that the Framers thought of the power to begin hostilities as different from the power to declare war. Under the Articles of Confederation, the nation's framework of government until the ratification, Congress operated as the executive branch of the United States. ${ }^{82}$ Article IX vested Congress with "the sole and exclusive right and power of determining on peace and war., ${ }^{, 83}$ Here the Framers (several of whom had served in the Continental Congress) ${ }^{84}$ had on hand a text that clearly and explicitly allocated to Congress the "sole and exclusive" authority to decide ("deterumiming on") whether to fight a war. If the Framers had intended to grant Congress the power to commence military hostilities, they could easily have imported the phrase from the Articles of Confederation into the Constitution, as they did with the powers adjacent to the Declare War Clause. ${ }^{85}$ For Professor Ramsey to

80 US Const Art I, $\$ 8, \mathrm{cl} 11$.

81 See Yoo, 84 Cal L Rev at 250-52 (cited in note 1). See also C. Kevin Marshall, Comment, Putting Privateers in Their Place: The Applicability of the Marque and Reprisal Clause to Undeclared Wars, 64 U Chi L Rev 953, 974-81 (1997) (describing use of letters of inarque and reprisal during the Revolutionary War).

82 See Yoo, 84 Cal L Rev at 236 (cited in note 1); Jerrilyn Greene Marston, King and Congress: The Transfer of Political Legitimacy, 1774-1776 303 (Princeton 1987) (arguing that "the executive and admmistrative responsibihties that had been exercised by or under the aegis of the king's authority were confided to the successor to his authority, the Congress").

83 Articles of Confederation Art IX (1777).

84 Jaines Madison, for example, had represented Virginia in the Congress, and his frustrations with the Articles of Confederation had led to his efforts to form a new Constitution.

85 Article IX also gave Congress the power to "establish[] rules for deciding, in all cases, what captures on land or water shall be legal," and "of granting letters of inarque and reprisal in tinues of peace." Articles of Confederation Art IX. Both provisions remained substantially unchanged in the Constitution, and, in fact, they appear in the same clause as the power to declare war. The Framers' alteration of Congress's authority from determining on peace and war to declaring war, while leaving the other provisions unchanged, indicates an intention to alter Congress's war power. 
be right, the Framers would have had to be clumsy draftsmen indeed, for they would have deliberately chosen more ambiguous, less defined words to achieve their meaning when clear examples lay readily at hand.

As a matter of methodology, it makes no sense to ignore a document as historically and legally significant as the Articles of Confederation. Professor Ramsey further fails to take into account the next most important documents: the state constitutions. Most of the state constitutions did not explicitly transfer to their assemblies the power to initiate liostilities, but rather sought to control executive power by disruptimg the structural umity of the executive branch. ${ }^{86}$ One state, however, chose to create exactly the type of arrangement contemplated by Professor Ramsey and otlier pro-Congress scholars. In its first 1776 constitution, Soutl Carolina vested in its chief executive the power of commander-in-chief, but then declared that "the president and commander-in-chief shall have no power to make war or peace ... without the consent of the general assembly and legislative council." ${ }^{\text {"7 }}$ In its 1778 constitution, South Carolina reaffirmed its decision that the legislature first must authorize war by stating that "the governor and commander-in-chief shall have no power to commence war, or conclude peace" without legislative approval. South Carolina's 1776 and 1778 constitutions bear two iniportant lessons. First, they show that the Framers did not understand the phrase "declare war" to amount to the power to "make war" or "commence war"-phrases the South Carolina constitution used to refer specifically to initiating war. Second, the South Carolina constitutions provide an example of constitutional language that clearly and explicitly created the very legislaturedommated warmaking system that Professor Ramsey and the proCongress camp favor. Yet, those scholars would have us believe that the Framers consciously established a specific system of legislative authorization by using far more ambignous, unclear language in the federal Constitution.

\section{The Meaning of Declare}

"Declare" carried a distinct and separate meanmg from "levy," "engage," "make," or "commence." As even Professor Ramsey would agree, his work focuses on the meaning of "declaring war" as used by legal scholars $\mathrm{m}$ the period preceding the ratification. He fails, how-

86 See Yoo, 84 Cal L Rev at 222-23 (cited in note 1); Adains, First American Constitutions at 271 (cited in note 17).

87 SC Const Art XXVI (1776), reprinted in Thorpe, ed, 6 The Federal and State Constitutions at 3247 (cited in note 24). 
ever, to examine how members of the framing generation would have understood those words. As an imitial matter, it is useful to examine the way these words were defined at the time of the ratification. As Professor Ramsey recognizes, Samuel Johnson's Enghish dictionary (widely used at the time) defined "declare" as: "to clear, to free from obscurity"; "to make known, to tell evidently and openly"; "to publisli; to proclaim"; "to shew in open view"; or "to make a declaration, to proclaim some resolution or opinion, some favour or opposition." This definition suggests that declaring war recognized a state of affairs and clarified the legal status of the United States's relationship with anotlier country, rather than authorized the steps to create that state of affairs.

Because lie immediately assumes that declaring war means beginning war, Professor Ramsey overlooks the definition of the otler words used in the Constitution itself in regard to war. Recall that Article I, Section 10 uses the phrase "engage in War," and Article III uses "levying War." Johnson, for example, defined "engage" as "to embark im an affair; to enter in an undertaking," or "to conflict; to fight.", Johnson defined "levy" as "to raise, applied to war." Other dictionaries of the period drew a similar distinction between "declare" and "engage" or "levy." Nathan Bailey's English dictionary defined "declare" as "to make known, to manifest, publish, or shew," while "engage" ineant "to encounter or figlit," and "levy" to "raise." Thoinas Slieridan's dictionary defined declare as "to make known," and engage as "to conflict, to fight," and levy as "to raise, to bring together men.", All three defined "coinmence," as used by the Soutl Carohina constitution, as "to begin." As far as I can determine, no authoritative source froin the framing period defines "declaring war" as commencing or beginning war, while several sources use other words to convey that meaning. Thus, the Constitution's use of the words "levy" or "engage in" war clearly refer to a more active role in warnaking, one more in hine with the autliorizing role that Professor Ramsey and others hope for im Congress. Even today, we commonly think of the statutes that establish public programs and mandates as "autlorization" statutes (to be followed by appropriations), not "declaring" statutes. A declaration does not autlorize or make, it recognizes and proclaims.

Properly understanding the meaning of "declare" also requires an exanimation of the founding generation's use of the word in other

\footnotetext{
88 Samuel Johnson, 1 A Dictionary of the English Language (W. Strahan 1755). 
contexts. When the Frainers einployed "declare" in a constitutional context, they usually used it in a juridical inanner, in the sense that courts "declare" the state of the law or the legal status of a certain event or situation. An example from early American political history illustrates this narrower meaning. When considering the meaning of declaring war, the Frainers' thoughts would have turned to their most significant national legal act, the Declaration of Independence. The Declaration did not "authorize" military resistance to Great Britain. At the time that the Continental Congress met at Philadelphia in 1776 to draft the Declaration, hostilities had existed for more than a year, and Congress had been exercising sovereign powers-negotiating with Britain, sendimg representatives abroad, seeking aid - for at least two years. ${ }^{93}$ Rather than authorize hostilities, the Declaratiou recognized the legal status of the relationship between the mother conntry and its foriner colories under imternational law. Thus, the Declaration appears in the form almost of a complaint, in which the revolutionaries count their grievances (taxation without representation, suspension of the laws, use of bench trials), the remedy sought (imdependence), and the applicable law ("the Laws of Nature and of Nature's God").

The Declaration of Independence's importance was not in authorizing combat, but in transforming the legal status of the hostilities between Great Britain and her colomies from an insurrection to a war between equals. As a historian recently observed in the William and Mary Quarterly, "[I]n order to turn a civil war into a war between states, and thus to create legitinate corporate combatants out of individual rebels and traitors, it was essential to declare war and to obtain recognition of the legitnnacy of such a declaration." Once a nationstate, the United States could make alliances and conduct commerce with other nations, which were critical steps in winning independence. The Declaration of Independence was the nation's first declaration of var."

93 See David Armitage, The Declaration of Independence and International Law, 59 Wm \& Mary Q 39 (2002).

94 See id; Yoo, 84 Cal L Rev at 246-47 (cited in note 1).

95 Armitage, $59 \mathrm{Wm} \&$ Mary $\mathrm{Q}$ at 39 (cited in note 93 ).

96 On a different note, unany state constitutions at the time of the framing contained declarations of rights that preceded the articles establishing the powers of the government. See John C. Yoo, Our Declaratory Ninth Amendment, 42 Ennory L J 967, 973-78 (1993) (describing declarations of rights in state constitutions before 1789). Unlike the Bill of Rights, these declarations did more than place limits on the enumerated powers of the government. Rather, they declared the existence of rights and powers inherent in the people and in individuals. The state declarations did not purport to authorize individual rights on the basis of positive law, but only sought to identify rights thought to pre-exist constitutional government. Again, a declaration did not create, but recognized. 
Professor Ramsey's response appears to be that, under international law, declaring war was basically useless. Therefore, the grant of authority in Article I, Section 8 must be the power to initiate hostilities. There are several problems with this reasoning. First, if Professor Ramsey is correct, the United States should never have issued a Declaration of Independence; events themselves demonstrated that hostilities had been authorized with the mother country. Nevertheless, the Declaration mattered because it openly proclaimed that the colonies had broken away, and it allowed other countries, such as France, to define their own legal relationships with the new nation. Second, if Professor Ramsey is right, the United States should never have taken the trouble to declare war the few tinies that it has. In each of the five declared wars, the United States could clain that it, its citizens, or its forces had been attacked. Third, if Professor Ramsey is to be believed, no nation should ever declare war, because apparently the launch of an offensive attack is sufficient to declare war. Yet, the British declared war several times in conflicts preceding the framing periodeven though these declarations often canie after hostilities had broken out."

Declarations of war serve a purpose, albeit one that does not amount to the sole authority to initiate hostilities. Declarations do simply what they say they do: they declare. To use the eighteenthcentury understanding, they make public, show openly, and make known the state of international legal relations between the United States and another nation. ${ }^{\text {s }}$ This is a different concept than whether the laws of war apply to the hostilities; two nations could technically not be at war, even though their forces might be engaged in himited combat. During the eighteenth century, declarations often took the form of a legal complaint in which a nation identified the grounds for waging war, explained the new rules that would apply to interaction between the two nations, and outlined the remedy. ${ }^{99}$ Declarations are also important for domestic constitutional purposes. Textually, a declaration of war places the nation in a state of total war, which triggers enhanced powers on the part of the federal government. ${ }^{100}$ Congress has recognized the distinction between declared total wars and non-

97 See Yoo, 84 Cal L Rev at 214-15 (cited in note 1).

98 Indeed, a full century after the founding, declaration continued to have meaning under international law. See, for example, Hague Convention (III) Relative to the Opening of Hostilities, art 1, Oct 18, 1907,36 Stat 2259.

99 See id at 215.

100 See, for example, US Const Amend V ("No person shall be held to answer for a capital, or otherwise infamous crime, unless on a presentment or indictment of a Grand Jury, except in cases arising in the land or naval forces, or in the Militia, when in actual service in time of War or public danger."). 
declared hostilities by providing the executive branch with expanded domestic powers-such as seizing foreign property, conducting warrantless surveillance, arresting enemy ahens, and taking control of transportation systems, to naine a few-only when war is declared. ${ }^{101}$ Even the Supreine Court has suggested that in times of declared war, certam actions by the federal government would survive strict scrutiny but would certainly fail if attempted in peacetime.

Finally, brief consideration of the interaction between the power to declare war and the President's powers suggests that Congress cannot have the sole authority to commence hostilities. Suppose Congress wanted to engage in war with France against the President's wishes. Even if Congress were to declare war against France, the President could still prevent hostilities from breaking out simply by refusing to order the armed forces to attack. All Congress can do is declare the state of the legal relationship between the United States and France under international law. Congress's power to declare war cannot aniount to the sole power to mitiate hostilities, because the Coinmander-in-Chief and Executive Power Clauses provide only the President with the power to conduct military operations, and thns a functional veto over any congressional effort to start a war.

\section{WAR AND THE CONSTITUTIONAL STRUCTURE}

Constitutional structure reveals, in even sharper contrast, the problems with a textualist interpretation of the Declare War Clause that requires congressional authorization of hostilities. In addition to ignormg the Constitution's use of "declare," Professor Ranusey fails to coinpare the Constitution's allocation of war powers with other provisions that govern the exercise of federal power. According to Professor Ramsey and other pro-Congress scholars, the Constitution estabhishes a strict procedure that requires Congress first to declare or authorize war before the President, as commander-in-chief, can prosecute hostilities. Yet, the Constitution itself nowhere describes such a process, nor does it explain how the Declare War Clause and the commander-in-chief power inust interact. The Frainers simply gave the former to Congress and the latter to the President and left it at that.

101 See, for example, 50 USC App § 5(b)(1) (1994 \& Supp 1999) (seizure of foreign property); 50 USC \$ 1811 (1994) (electronic surveillance), 50 USC $\$ 1829$ (1994) (physical searches), 50 USC $\$ 1844$ (Supp 1999) (trap and trace devices); 50 USC $\$ 21$ (1994) (seizure of aliens); 10 USC $\$ 2644$ (1994 \& Supp 1996) (seizure of transportation systems).

102 Korematsu v United States, 323 US 214, 216 (1944) (upholding racial classifications during World War II and noting that "legal restrictions which curtail the civil rights of a single racial group" may be justified by "[p]ressing public necessity"). 
Although Professor Ramsey's reading fails to provide a textbased explanation of its Congress-first process, his argument might be thought of as more of a structural one. He reads the Declare War Clause to mean more than a power to issue a declaration of war because otherwise it would impose no substantive himit on the President. ${ }^{103}$ Imphicit in this central idea is that the Constitution's structure requires that a check on the President's war powers must exist. Ramsey's argument, however, misunderstands the nature of the Constitution's basic structure. Congress needs no check on the President through the Declare War Clause because it already possesses all the power it needs. Congress at any time may use its power of the purse to counter presidential warmaking. Indeed, all Congress need do is nothing; by refusing actively to authorize the existence of armed forces or appropriate additional money to fund wars, Congress can prevent the nation from conducting any effective hostihties. Professor Ramsey and others seek to infuse an unwarranted meaning in the Declare War Clause to solve a constitutional problem that is not really there.

\section{A. Reading the Constitution as a Whole}

The constitutional text makes apparent that when the Framers wanted to make legislative participation a constitutional requirement in the exercise of executive functions, they knew how. For example, neither Professor Ramsey, other pro-Congress scholars, nor I dispute that under the British constitution, the power to make war was executive. Pro-Congress scholars simply believe that the Constitution divided the war power between the President and Congress, with Congress playing the chief role in deciding whether to wage war, and the President controlling how to wage war. When the Constitution, however, divides and allocates executive powers in the manner suggested by Professor Rainsey, it does so far more clearly than the manner im which it divorced the declare war power from the other executive war powers. This indicates that the Framers did not intend war powers to be governed by a specific legalist process akin to others in the Constitution.

The Treaty and Appointments powers provide a useful illustration of this point. Article II, Section 2, for example, states that the President "shall have Power, by and with the Advice and Consent of the Senate, to make Treaties, provided two thirds of the Senators present concur." ${ }^{\text {,104 }}$ This provision makes clear that the President cannot make treaties without senatorial consent, and it establishes a mini-

103 See Ramsey, 69 U Chi L Rev at 1600-01 (cited in note 4).

104 US Const Art II, \$ 2, cl 2. 
mum process for the making of treaties. Similarly, Article II requires senatorial participation in the making of appointments, another power that was executive in nature under the British constitution. Section 2 states that the President "shall nominate, and by and with the Advice and Consent of the Senate, shall appoint Ambassadors, other public Ministers and Consuls, Judges of the Supreme Court, and all other Officers of the Umited States.",

If the Framers had sought to establish the warmaking system that Professor Ramsey envisions, why didn't they use the same framework? Article II, Section 2 could have imcluded an additional clause that the President "shall have Power, by and with the advice and consent of Congress, to engage in War." This would have made clear that the Constitution requires Congress's permission when beginning military hostilities, just as the President now needs senatorial consent before making treaties or appointing Supreme Court Justices. Instead, Professor Ramsey and other pro-Congress scholars would have us believe that the Framers imeptly chose ambiguous, obtuse language to allocate war powers in such a manner as to reacl the same functional result as the Treaty and Appointments Clauses. To be sure, these provisions raise their own imterpretive questious, which I have addressed elsewhere, ${ }^{105}$ but they take the form of crystals of brilliant clarity when placed besides the war power clauses.

The absence of a textually mandated and defined process for going to war is especially clear because the Constitution, im otler areas, provides for specific processes when they are wanted. A comparison to the process for enacting statutes is illustrative. Althougl one of the signal defects of the Articles of Confederation was its imability to directly regulate the private conduct of individuals, the Framers still sought to render the passage of legislation difficult. Article I, Section 7 thus sets out a finely wrought method for making public laws, witl exphicit provisions when the consent of different parties, sucl as the President, is required. ${ }^{100}$ It does not describe the legislature's role in lawmaking in Article I, aud then the President's veto power in Article II, while leaving blank how the twam shall meet. Similarly, Article V describes a process for amending the Constitution-one in whicl

$105 \mathrm{Id}$.

106 See John C. Yoo, Globalism and the Constitution: Treaties, Non-Self-Execution, and the Original Understanding, 99 Colum L Rev 1955 (1999) (examining whether treaties are non-selfexecuting); John C. Yoo, The New Sovereignty and the Old Constitution: The Chemical Weapons Convention and the Appointments Clause, 15 Const Commentary 87 (1998) (discussing application of the appointınents clause to international organizations).

107 See generally Bradford R. Clark, Separation of Powers as a Safeguard of Federalism, 79 Tex L Rev 1321 (2001). 
Congress can exercise the initiative-in which the consent of several actors is precisely outlined. Contrast this with Professor Ramsey's process for warmaking, which he believes is just as precise: Congress must provide a declaration of war (presumably by simple majority vote) before the President can exercise his commander-m-chief functions on the battlefield. If warmaking were to have such process features, involving congressional initiative and consent, we would expect the constitutional text to establish as detailed a procedure for warmaking as for lawmaking or amending the Constitution. Surely, the Framers would have thought war to be as important as the latter two subjects.

\section{B. War Powers and the Structure of the Executive Power}

In light of these textual and structural defects with Professor Ramsey's argument, I think it fair to say that, at best, his arguinent amounts to a claim that the Constitution does not clearly allocate the power to commence war in the President. His resort to the international legal scholarship of the eighteenth century constitutes an effort to show that "declaring war" means more than it appears to mean, and that the many presidents who have read their textual powers to grant thein the authority to commence military hostilities have been in the wrong. Yet, even if Professor Ramsey were successful in introducing doubts into the pro-executive interpretation of the constitutional text, the deeper design of the Constitution itself requires us to construe any ambiguities in the scope of the executive power in favor of the President. Several structural features of the Constitution indicate that any uncertamty in the authority to initiate military hostilities must be resolved by vesting those powers in the President.

First, the Constitution secures all federal executive power in the President to ensure a unity in purpose and energy im action. As Alexander Hamilton famously observed in the Federahist 70, "Decision, activity, secrecy, and dispatch will generally characterize the proceedings of one unan in a much more eminent degree than the proceedings of any greater number." ${ }^{108}$ The centralization of authority in the President is particularly crucial in matters of national defense, war, and foreign policy, where a unitary executive can evaluate threats, consider policy choices, and mobilize national resources with a speed and energy that is far superior to any other branch. As Hamilton noted, "Energy in the executive is a leading character in the definition of good government. It is essential to the protection of the community against foreign at-

108 Federalist 70 (Hamilton), in Rossiter, ed, Federalist Papers at 424 (cited in note 38). 
tacks." ${ }^{, 109}$ This point applies perhaps most directly in war than m any other context. Wrote Hamilton: "Of all the cares or concerns of government, the direction of war most peculiarly demands those qualities which distinguish the exercise of power by a single hand."110

Second, the constitutional structure requires that any ambiguities in the allocation of a power that is executive in nature, such as the power to conduct military liostilities, must be resolved in favor of the executive branch. Article II, Section 1 provides that " $[t]$ he executive Power shall be vested in a President of the Umited States." trast, Article I's Vesting Clause gives Congress only the powers "herein granted." 112 This difference in language indicates that Congress's legislative powers are limited to the enumeration in Article I, Section 8, while the President's powers include inherent executive powers that are unenumerated in the Constitution.

To be sure, Article II lists specifically enumerated powers in addition to the Vesting Clause, and some have argued that this limits the "executive Power" granted in the Vesting Clause to the powers on that list. ${ }^{113}$ But the purpose of the enumeration of executive powers in Article II was not to define and cabim the grant in the Vesting Clause. Rather, the Frainers redirected some elements of powers of the executive power to Congress in Article I, while expressly maintaining other elements as enumerated executive powers in Article II. Hence, for example, they gave the King's traditional power to declare war to Congress under Article I, while the commander-in-chief authority was expressly reserved for the President in Article II. Furtliermore, the Framers altered other plenary powers of the King, such as treaties and appointments, assigning the Senate a share of then in Article II itself. ${ }^{14}$ Thus, the enumeration in Article II marks the places where sev-

109 Id at 423.

110 Federalist 74 (Hamilton), in Rossiter, ed, Federalist Papers at 447 (cited in note 38). Jaines Iredell (later an Associate Justice of the Supreine Court) argued in the North Carolina Ratifying Convention that "[f]roin the nature of the thing, the command of armies ought to be delegated to one person only. The secrecy, despatch, and decision, whicl are necessary in military operations, can only be expected from one person." Elliot, ed, 4 Debates at 107 (cited in note 45). See also Joseph Story, Commentaries on the Constitution of the United States 546-47 (Carolina 1987) (stating that in military matters, "[u]mity of plan, promptitude, activity, and decision, are indispensable to success; and these can scarcely exist, except when a single magistrate is entrusted exclusively with the power").

111 US Const Art II, $\S 1, \mathrm{cl} 1$.

112 US Coust Art I, $\$ 1$.

113 See, for example, A. Michael Froomkin, The Imperial Presidency's New Vestments, $88 \mathrm{Nw}$ U L Rev 1346, 1362-66 (1994) (rejecting the argument that Congress lacks constitutional authority to restrict the President's power over executive brancl officials).

114 Thus, Article II's enumeration of the Treaty and Appointinents Clauses only dilutes the umitary nature of the executive branch in regard to the exercise of those powers, rather than transforming thein into quasi-legislative functions. See Yoo, 99 Colum L Rev at 2233-34 (cited in 
eral traditional executive powers were diluted or reallocated. The Vesting Clause, however, conveyed all other unenumerated executive powers to the President. As Alexander Hamilton famously argued in the Helvidius-Pacificus debates, "The general doctrine of our Constitution, then is, that the executive power of the nation is vested in the President; subject only to the exceptions and qualifications which are expressed in the instrument."115

There can be hittle doubt that the decision to deploy military force is "executive" in nature and was traditionally regarded as such. It calls for action and energy in execution, rather than the dehiberate formulation of rules to govern the conduct of private individuals. Moreover, the Framers understood it to be an attribute of the executive. "The direction of war inples the direction of the common strength," wrote Hamilton, "and the power of directing and einploying the common strength forms a usual and essential part in the definition of the executive authority." ${ }^{\text {"116 }}$ As a result, to the extent that the constitutional text does not explicitly allocate the power to initiate military hostilities to a particular branch, the Vesting Clause provides that it remain among the President's unenumerated powers in foreign affairs. Hamilton's argument about the Vesting Clause should not be surprising to Professor Ramsey, who, when writing with Sai Prakash in other areas of foreign affairs law, has heavily relied upon it. ${ }^{17}$ In areas such as treaty termination, for example, Professor Ramsey (with Professor Prakash) has been only all too willing to embrace the notion of unenumerated executive foreign affairs powers. ${ }^{118}$ Yet, on the question of war powers he inexphicably reverses the polarity of the constitutional structure to claim that the text hems in the President. A consistent approach to the constitutional structure and executive power in foreign affairs ought to find presidential authority both to initiate military hostilities and to terminate treaties."

Third, depriving the President of the power to decide when to use military force would disrupt the basic constitutional framework for the conduct of foreign relations. From the beginning of the Republic, the vesting of the executive, commander-in-chief, and treaty powers in

\footnotetext{
note 16).

115 Pacificus No 1, in Henry Cabot Lodge, ed, 4 Works of Alexander Hamilton 432, 439 (G.P. Putnam's Sons 1904), quoted in Myers v United States, 272 US 52, 138-39 (1926).

116 Federalist 74 (Hamilton) at 447 (cited in note 110).

117 See generally Prakash and Ramsey, 111 Yale L J at 256-61 (cited in note 75).

118 See id at 264-65, 324-27 (describing examples of such powers).

119 On this question, at least, iny positions have the virtue of remaining consistent. See John Yoo, Politics as Law?: The Anti-Ballistic Missile Treaty, the Separation of Powers, and Treaty Interpretation, 89 Cal L Rev 851, 869-77 (2001) (stating that the President has plenary authority to terminate, suspend, or interpret treaties).
} 
the executive branch has been understood as granting the President plenary control over the conduct of foreign relations. As Secretary of State Thomas Jefferson observed during the first Washington administration: "The constitution has divided the powers of government into three branches [and] has declared that 'the executive powers shall be vested in the president,' submitting only special articles of it to a negative by the senate." ${ }^{120}$ Due to this structure, Jefferson continued, "[t] he transaction of business with foreign nations is executive altogether; it belongs, then, to the head of that departinent, except as to such portions of it as are specially submitted to the senate. Exceptions are to be construed strictly." ${ }^{121}$ In defending President Washington's authority to issue the Neutrality Proclamation, Hamilton came to the same interpretation of the President's foreign affairs powers. According to Hamilton, Article II "ought . . . to be considered as intended . . . to specify the principal articles imphed in the definition of executive power; leaving the rest to flow from the general grant of that power."12 As future Chief Justice John Marshall famously declared a few years later, "The President is the sole organ of the nation in its external relations, and its sole representative with foreign nations. ... The [executive] departınent ... is entrusted with the whole foreign mtercourse of the nation." ${ }^{123}$ Given this agreement, it has not been difficult for the executive branch consistently to assert the President's plenary authority in foreign affairs ever since.

A final structural point is worth emphasizing. Much of the support for broadly interpreting the power to declare war, it seems to me, arises out of concerns about unchecked presidential warmaking. In Professor Ramsey's view, for example, the Declare War Clause must encompass the power to commence hostilities, because otherwise it would impose no substantive limit on the President. ${ }^{124}$ Professor Ramsey's argument tries to show that declarations of war are so meaningless that the Constitution's reference to them must portend some greater power-even if that power is not borne by the text's actual meaning. Thus, like other pro-Congress scholars before him, Professor Ramsey seeks to convert declaring war, which specifically functioned under international law to determine the legal status of hostilities, into a domestic legal check on the executive branch. Otherwise, Congress simiply cannot control the President!

120 Thomas Jefferson, Opinion on the Powers of the Senate (1790), in Paul L. Ford, ed, 5 The Writings of Thomas Jefferson 161 (G.P. Putnam's Sons 1895).

121 Id.

122 Pacificus No 1, in Lodge, ed, 4 Alexander Hamilton at 439 (cited in note 115)

12310 Annals of Congress 613-14 (Gales and Seaton 1851).

124 See Ramsey, 69 U Chi L Rev at 1600-01 (cited in note 4). 
Such concerns, however, misunderstand the Constitution's grants of power to Congress in war matters, which give it an effective role in the coinmencement of military hostilities. Congress, for exannle, has the sole authority to "raise and support Armies," to "provide and maintain a Navy," and to "make Rules for the Government and Regulation of the land and naval Forces."125 Without the legislative establishment and funding of the armed forces, presidents have no weapons with which to wage war. The appropriations power and the power to raise the military give Congress a sufficient check on presidential warmaking, a concept that the Frainers well understood. In fact, in the America of the late eighteenth century, presidents did not enjoy the resources to commence ineaningful hostilities on their own. After the peace with Great Britain, the United States did not immediately maintain a large peacetime army or navy and did not really do so until the Cold War. In the nation's first military conflict under the Constitution, President Washington continually had to seek congressional funding for campaigns against Indian tribes. ${ }^{126}$ In fighting the Quasi-War with France (the nation's first war against a European nation under the Constitution, which, incidentally, was not accompamed by a declaration of war even though the United States had not been attacked), President Adains had to seek congressional approval for a navy and army with which to conduct hostilities. ${ }^{127}$ In the course of approving these measures, Congress fully discussed the merits of the wars, and it easily could have prevented the cominencement of hostilities simply by refusing to appropriate anything.

This pattern has been repeated in our recent modern wars. In the war against the al Qaeda terrorist organization and the Taliban militia in Afghanistan, for example, President George W. Bush sought additional funding for military operations, giving Congress the opportunity to oppose hostilities. ${ }^{128}$ Similarly, in 1999 President Clinton sought einergency funding for military operations in Kosovo and Serbia. ${ }^{129}$ In both cases, Congress could have effectively blocked the conduct of hostilities by refusing to appropriate the funds. Professor Ramsey's

125 US Const Art I, \$ 8, cl 12-14.

126 See Richard H. Kohn, Eagle and Sword: The Federalists and the Creation of the Military Establishment in America, 1783-1802 97-98, 110-11, 120-24 (Free Press 1975).

127 See Alexander DeConde, The Quasi-War:The Politics and Diplomacy of the Undeclared War with France 1797-1801 90-96 (Charles Scribner's Sons 1966).

128 See Kathy A. Gambrell, Bush to Seek $\$ 48$ Billion for Defense, United Press International (January 23,2002), available online at <http://www.lexis.cons > (last visited Oct 2, 2002) (explaining details of Bush's requests for more money for the fight against terrorisn1).

129 See Yoo, 148 U Pa L Rev at 1681 (cited in note 1) ("Congress doubled the Administration's request for emergency funding for Yugoslavia war operations, to the tune of $\$ 11.8$ billion, but did not authorize the war."). 
structural argument-that the Declare War Clause must give the power to Congress to decide whether to commence hostilities, because otherwise it would give Congress no check on the President-simply looks for the answer in the wrong places. There is no doubt that the Constitution provides Congress with a powerful check on warmaking, but it comes through the authority to grant or deny funds to wage war.

This Part has described the textual and structural problems with Professor Ramsey's approach. Professor Ramsey's fundamental problem is that his narrow focus on the Declare War Clause ignores clear signs in the constitutional text and structure that the President enjoys significant initiative in warmaking. Tellingly, Professor Ramsey provides no textual or historical interpretation of the Commander-mChief or Executive Power Clauses, which provide a vast reservoir of authority for presidents im foreigu affairs and national security. Further, he ignores other constitutional provisions in which the Framers demonstrated that they understood "declaring war" as far narrower than "conducting war," a distinction further illuminated by the common understanding of "declare" im the mid-eighteenth century. $\mathrm{He}$ also cannot explam why the Framers refused to follow clear models in the text of the Articles of Confederation, the state constitutions, and the Constitution itself that would have clearly and unambiguously required legislative consent for the mitiation of hostilities. Fmally, his approach directly conflicts with the Constitution's structure, which creates a system that was not to be subject to a strict, legahistic process and im which the executive branch was to enjoy any unenumerated foreigu affairs and national security powers.

\section{CONCLUSION}

This Response sought to accomplish two missions. First, it attempted to demonstrate that Professor Ramsey's use of history suffers from significant flaws. His effort to show that the Framers understood the phrase "declaring war" as vesting Congress with the sole power to begin military hostilities did not use history in the right way, took the wrong lessons from the relevant primary sources, and failed to take account of the historical works on early American constitutional development. Second, this Response has sought to distill the textual and structural arguments im favor of a flexible approach to war powers. Careful examination of the central provisions imvolved, other relevant texts, and the constitutional structure shows that the Constitution does not mandate a specific, legahistic process for waging war. Instead, the Constitution vests the executive and legislative branches with different powers mvolving war, which the President and Congress may use to cooperate or to compete. The flexibility of the constitutional framework for warnaking becomes clear when compared to, for ex- 
ample, the Constitution's procedures for enacting a statute, ratifying a treaty, or appointing officers of the United States. If the Framers had intended the Constitution to impose the strict process demanded by Professor Ramsey and other pro-Congress scholars, they would have employed the more detailed mechanisms and language that they used elsewhere.

While the debate over war powers is of great intellectual interest, it is important to remember that it has significant practical imphications as well. Professor Ramsey's approach, like that of other proCongress scholars, has three primary effects on the conduct for American national security in the modern world. First, a legahistic system that requires congressional authorization of all hostilities would find many, if not most, wars waged since the dawn of the atomic age (and before) to be unconstitutional. Under Professor Ramsey's theory, conflicts ranging from the Korean War in 1950 to the intervention in Kosovo in 1999 flatly violated the Constitution due to the lack of congressional authorization for the hostilities. Given the miperatives for quick and decisive military action in the modern world, and Congress's demonstrated preference to allow the President to lead, it seems unlikely that this practice will change. Professor Ramsey and his colleagues, therefore, seek to overthrow the operating system of war powers that has been in existence since at least the end of World War II, with the acquiescence of the three branches of government.

Moreover, Professor Ramsey's theory renders trivial those times that the nation has taken the serious step of declaring war. In all five of our declared wars, the United States could make a strong case that it was attacked. According to Professor Ramsey, in such cases a declaration of war is wholly unnecessary. Indeed, under Professor Ramsey's approach, the presidents and Congresses have behaved rather perversely over the last two centuries, by declaring war when they didn't need to and faiting to declare war when they did.

Second, Professor Ramsey, like other pro-Congress scholars, must admit that his approach contemplates a dramatic expansion of the judicial role in foreign affairs. If the President orders imilitary hostilities without congressional authorization, then he has violated the Constitution, and presumably a properly situated plaintiff-such as a reservist called to duty-could bring a challenge in federal court to a war. Judicial intervention in war would have two obviously deleterious effects. It would seriously undermine the ability of the President to protect the national security-imagine the consequences if the President were constantly forced to await judicial resolution of a case before using force abroad to protect the nation's interest. A broader judicial role in warmaking also would threaten defiance of the federal courts; if there ever were a situation in which a President would feel the need 
to disregard a judicial order, it would be in a case in which he beheved his actions were necessary to protect the nation with military force. And it goes without saying that Professor Raunsey's theory would foist upon the federal courts a job that they do not want-witness the D.C. Circuit's recent holding that the constitutionality of the Kosovo war was nonjusticiable. ${ }^{130}$

Third, Professor Ramsey and other pro-Congress scholars would impose upon the country a strict, legalistic process for making war precisely at a time when utmost flexibility is required. Forcing presidents to receive congressional authorization before using force would seriously hamper the nation as it confronts the unprecedented challenges posed by terrorist organizations and rogue nations. According to Professor Ramsey's approach, for example, American attacks against terrorists, when not authorized by statute, would fall afoul of the Constitution. Thus, President Reagan's strike on Libya in 1986, and President Clinton's missile attack on Sudan and Afghanistan targets im 1998 were illegal and, one imagines, possibly subject to judicial injunction or damages. This view would place serious restrictions on the United States's ability to respond to the terrorist attacks of September 11,2001. Although Congress has approved the use of forcethough not declared war-against those connected with the September 11 attacks, ${ }^{131}$ it has not provided legislative authorization for military attacks agamst terrorist groups uncomiected with the Septeniber 11 attacks, or the nations that harbor them. Thus, even if the President beheves certam terrorist groups and rogue nations pose a future threat to the United States by, for example, attempting to acquire weapons of mass destruction, Professor Ramsey and others would prevent him fronl attacking such potential enemies unless Congress declared war or the Umited States suffered an attack first. One can only miagine the advantage that terrorists or rogue nations would draw from public congressional dehberations, which might give then the advance notice of a possible attack necessary to conceal their forces or disperse their weapons facilities.

Properly understood, the Constitution does not require such a result. As this Response has demonstrated, the Constitution's text and structure allow a flexible system of war powers in which the President can seize the mitiative to wage war, subject to congressional control over funding. It is a systen that not only has proven stable for at least the last half-century, if not before, but one that einpowers the nation to take the measures necessary to fight the new type of war that was

130 See Campbell v Clinton, 203 F3d 19,25 (DC Cir 2000).

131 Authorization for Use of Military Force, Pub L No 107-40, 115 Stat 224 (2001). 
thrust upon it on September 11, 2001. Instead of using the Constitution to fight the last war, we should understand that the Constitution allows us to respond to the next. 